\title{
Insights into Seasonal Dormancy of Perennial Herbaceous Forages
}

\author{
Laxman Adhikari'1, Rasyidah M. Razar'1, Dev Paudel'2, Ruyue Ding1, \\ Ali M. Missaoui ${ }^{*}$ \\ ${ }^{1}$ Institute of Plant Breeding Genetics and Genomics, University of Georgia, Athens, GA, USA \\ ${ }^{2}$ Agronomy Department, University of Florida, Gainesville, FL, USA \\ Email: *cssamm@uga.edu
}

How to cite this paper: Adhikari, L., Razar, R.M., Paudel, D., Ding, R. and Missaoui, A.M. (2017) Insights into Seasonal Dormancy of Perennial Herbaceous Forages. American Journal of Plant Sciences, 8, 2650-2680. https://doi.org/10.4236/ajps.2017.811179

Received: August 5, 2017

Accepted: October 13, 2017

Published: October 16, 2017

Copyright $\odot 2017$ by authors and Scientific Research Publishing Inc. This work is licensed under the Creative Commons Attribution International License (CC BY 4.0).

http://creativecommons.org/licenses/by/4.0/ (c) (i) Open Access

\begin{abstract}
Seasonal dormancy is an adaptive mechanism where plants suspend growth and become physiologically inactive to avoid extreme environmental conditions. Environmental factors like temperature, photoperiod, nutrients, and soil moisture control plant growth and development through various complex molecular mechanisms. Crown and seed dormancy of plants are mostly influenced by day length and temperature. Genes and physiological pathways triggered by these two factors along with genotype variability are some targets to manipulate seasonal dormancy. There is genetic variation in the depth and duration of seasonal dormancy. Therefore, their genetic manipulation is possible. Manipulations of summer and fall dormancy are relatively easier compared to winter dormancy because plants require protection of their apical meristem from freezing temperatures and limited water supply. Genetic factors that regulate seed dormancy may also have regulatory role for seasonal dormancy of the maternal plants. Limited genetic and genomic information are available for seasonal dormancy in herbaceous perennial species. Knowledge of genes controlling seasonal dormancy of eudicots, forest trees, and horticultural crops could be interpolated to explore possible dormancy mechanisms in perennial forages. This study reviews current knowledge of seasonal dormancy of herbaceous forages emphasizing the genetic and physiological context that would be valuable to breeders and plant biologists to expand the production season of perennial species by developing non-dormant and semi-dormant cultivars.
\end{abstract}

\section{Keywords}

Herbaceous Perennials, Seasonal Dormancy, Genes, Endodormancy, Forages, Hormones 


\section{Introduction}

Herbaceous forage grasses and legumes are the cornerstone of feed resources for livestock and food security globally [1]. In the USA, forage ecosystems include more than 1500 grass species and 4000 legume species [2]. Forages are also valuable for their roles in wildlife habitat, watersheds, land conservation, soil reclamation, bioenergy, and sustainable agricultural systems [3]. Forage crops are either grazed directly on pasture or transported as hay, silage, green-chop, and pellets [4]. Forage species include both annual and perennial species and are categorized into cool season and warm season based on their primary growth period and availability [5]. Cool-season species, also known as temperate forages perform best at temperature ranges from $20^{\circ} \mathrm{C}$ to $25^{\circ} \mathrm{C}$. Both high $\left(>30^{\circ} \mathrm{C}\right)$ and low $\left(<10^{\circ} \mathrm{C}\right)$ temperatures affect plant growth and development causing a major yield reduction [6]. Many of these temperate crops exhibit C3 carbon fixation pathway (http://forages.oregonstate.edu).

Warm-season grasses evolved mostly in subtropical climates and perform optimally at temperature of $30^{\circ} \mathrm{C}-35^{\circ} \mathrm{C}$. Plant growth begins when soil temperature reaches $15^{\circ} \mathrm{C}-20^{\circ} \mathrm{C}$ (http://forages.oregonstate.edu). Warm-season crops exhibit $\mathrm{C} 4$ carbon fixation pathway and are efficient in fixing atmospheric carbon dioxide. These grasses are excellent alternative forage sources in summer when cool season grasses are not abundant [7]. An ideal seasonal distribution of forages can be obtained by a combination of cool and warm-season species which helps avoiding fodder gaps (Table 1). To meet the increasing demand in feed, manipulation of seasonal dormancy is a potential target to improve the annual forage production and seasonal distribution of perennial species.

Seasonal dormancy is the state where a plant becomes physiologically inactive and its growth is reduced or suspended for a certain time period [8]. Seasonal dormancy was suggested as an essential feature for perenniality. It enables plants to avoid and survive unfavorable environmental conditions such as summer heat and drought or winter freeze [9]. Forage species Festuca arundinacea, Poa scabrella, P. bulbosa, P. secunda, Hordeum bulbosum L., Dactylis glomerata ssp. and Hispanica "Kasbah" exhibit summer dormancy [10] [11], and alfalfa (Medicago sativa L.) [12], pensacola bahia grass (Paspalum notatum) and bermudagrass (Cynodon dactylon L.) [13] [14] [15] exhibit fall/winter dormancy. Winter dormancy is prevalent in several perennial herbaceous species and deciduous trees [16]. Seed and bud dormancy also exist in several plant species leading to delay in germination and flowering time [17]. The underlying mechanisms of the different forms of dormancy may have some similarities because all of them are more or less controlled by photoperiod, temperature, and endogenous factors. Meristems and crowns are the major plant organs perceiving signals for seasonal dormancy [18]. Shifting from the active growth to dormancy involves complex developmental, genetic and metabolic processes. Nutrient remobilization from shoots to crowns inhibits meristematic activity in buds and plants cease growth [19]. Therefore, understating the ecological and endogenous processes controlling 
Table 1. Thirty common forages and their availability in Georgia and southeast leading to complete to partial forage deficiency.

\begin{tabular}{lllllllllll}
\hline Jan & Feb Mar Apr Nay & May & June
\end{tabular}

\section{Cool-season forages}

Alfalfa

Tall Fescue

Red clover

Orchadgrass

White clover

Perennial ryegrass

Bluegrass

Annual ryegrass

Barley

Oat

Cereal Rye

Wheat

Arrowleaf clover

Ball clover

Triticale

\section{Warm-season forages}

Corn

Foxtail millet

Sorghum

Crabgrass

Forage soybean

Pearl millet

Teff

Browntop millet

Bahiagrass

Bermudagrass

Dallisgrass

Johnsongrass

Big bluestem

Indiangrass

Switchgrass

Source: http://www.caes.uga.edu/ and http://plants.usda.gov/; Note: ${ }^{+}$availability; ' ${ }^{-}$non-availability; ${ }^{+/}$limited availability. 
seasonal dormancy is valuable for the manipulation of this trait through breeding and genetic technologies to improve crop yields and persistence.

In this review, we discuss the types of seasonal dormancy in herbaceous forage species and the potential for manipulating these traits to improve forage production and seasonal distribution. We provide insights into the possible genetic and genomic factors controlling seasonal dormancy of vegetative buds and seeds of common herbaceous species with focus on the roles of photoperiod and temperature in controlling such traits. We also compile published information on genes and genomic features of some eudicots that could be extrapolated to infer the underlying molecular basis of grass seasonal dormancy.

\section{Forage Gaps Resulting from Seasonal Dormancy}

Overcoming the forage deficit during the dormancy season of perennial forage species (Table 1) presents a major challenge to livestock producers. Farmers often resort to growing annual species such as wheat (Triticum aestivum), triticale (x Triticosecale spp.), Elytricum spp., Brassicarapa, B. oleracea, grasspea (Lathyrus sativus $\mathrm{L}$.) etc. to fill the gap resulting from growth suspension of dormant species [20] [21] [22]. However, most farmers have limited land areas, and perennial crops may not be compatible with growing other annuals to reduce the herbage deficit. The best strategy to mitigate forage shortage is by reducing the span of seasonal dormancy of perennials species and develop semi or non-dormant germplasm. Growing cool season forages could partially help filling the seasonal forage gaps that occur in late fall, winter and early spring as a result of dormancy of warm season species. It is worth noting though that some of the most valuable cool-season perennial forages such as alfalfa exhibit fall/ winter dormancy in temperate environments. Although no precise data is available on the economic loss due to seasonal forage dormancy, there is substantial evidence from hay feeding and supplementation that there is an economic effect on the farm economy due to the seasonal gaps in herbage availability.

\section{Types of Seasonal Dormancy}

\subsection{Summer Dormancy}

Summer dormancy (SD) refers to the temporary growth cessation of some plant species in the summer season even under favorable soil moisture conditions [23]. It is an evolutionary response that some grasses adopted as an avoidance strategy to escape summer drought and heat [24] [25] [26] [27]. Numerous ecotypes of cool-season perennial grasses originating from the Mediterranean Basin of southern Europe and northern Africa, and the Mediterranean environments of California exhibit summer-dormancy, primarily in response to increasing day length and probably high temperatures [9] [24] [28]. Summer dormant grasses resume their growth once moisture is adequate [29]. For example, temperate grasses in semi-arid and arid Mediterranean regions such as Cocksfoot (Dactylis spp.), tall fescue and canary-grass exhibit SD to escape drought stress [30]. The 
specific characteristics of the summer dormant plants include no or low leaf development, increased senescence of mature leaves, and generation of quiescent organs [11]. Several reports highlighted the relationship between summer dormancy and drought stress, concluding that SD provides superior survival under drought stress [31] [32]. Under extreme dry summers, SD is considered as an indicator of drought tolerance in cool-season grasses such as tall fescue, where survival and persistence of various cultivars of contrasting dormancy fluctuated with summer drought stress [33]. Therefore, growing summer-active fescue cultivars under conditions of limited moisture is not recommended [33]. Similar observations for the relationship of dehydration tolerance and SD were reported in other perennial grasses such as, orchardgrass (Dactylis glomerata L.), pine bluegrass (Poa scabrella) [24], bulbous bluegrass (P. bulbosa) [34] [35] and Hordeum bulbosum [36]. Because of the common manifestation of both trait such as leaf desiccation, defoliation, and reduced growth, characterizing SD and dehydration-tolerance is a confounding job under severe drought, although they are independent responses [31]. Thus, dormancy testing should be carried out only in plants growing under sufficient soil water condition [23].

\subsubsection{Characteristics of Summer Dormancy}

Based on the regulatory factors, summer dormancy has been classified into two types: eco-dormancy and endo-dormancy [37]. Eco-dormancy, also called enforced dormancy, is caused by the lack of suitable environmental conditions. The plant resumes growth once it regains the standard amount of water, temperature, and other factors which were previously limiting [10]. On the other hand, plants undergoing endo-dormancy, also referred to as physiological dormancy, will remain dormant even when environmental factors are favorable until the physiological pathways relaxes and releases dormancy [10] [11]. Eco-dormancy is regulated mostly by environmental factors through complex interaction of stress responses [11]. Summer-dormant cool-seasonal perennial grasses produce dormant regenerating buds at tiller bases during spring, from which growth resumes in response to increased water availability and decreasing temperatures in autumn. Regulation of endo-dormancy involves complex physiological processes regulated by various genes, hormones, as well environmental responses like temperature and photoperiod [11]. Temperature and photoperiod affect endo-dormancy in plants through the regulation of timing of reproductive maturity, and meristem activities [33]. Effects of temperature and day length on summer dormancy in different species have been reported elsewhere. Endo-dormancy is induced independently from soil moisture, even though it can be accelerated by drought [33]. The process is most likely initiated under short photoperiods and relatively low temperatures during winter. Orchardgrass (Dactylis glomerata L.) and tall fescue [Lolium arundinaceum (Schreb.) S.J. Darbyshire] must be exposed to these conditions for the summer dormancy trait to be fully expressed under the subsequent long photoperiods and high temperatures of summer [33] [38]. Metabolic activity in the summer dormant D. glomerata 
was found to be reduced when tested using biochemical and physiological experiments. Monosaccharides content decreased in the leaf blades of dormant plants even before summer [39]. Two levels of summer dormancy are defined; complete dormancy and incomplete dormancy [33]. A complete summer dormant plant suspends growth for at least four weeks in summer with dehydration of living parts and senescence of herbage as in cock's-foot grasses (Dactylis spp.) [38]. Incomplete summer dormancy occurs if the plant shows moderate dormancy symptoms such as some genotypes of tall fescue [11]. Differences between dormancy types may be gradual and depend on responsiveness to inductive and synergistic factors (i.e. day length, high temperature, soil moisture status), depth of dormancy induction and kinetics of dormancy relaxation during summer [10].

Summer dormant and semi-dormant cool-season grasses have been considered ideal to grow in regions with prolonged hot summers to avoid desiccation [11]. For instance, obligatory dormant tall fescue germplasm or the semi-dormant Harding grass (Phalaris aquatica L.) is thought to be ideal for the U.S. Southern Great Plains for better persistence [40] [41]. Along with improved persistence, summer dormant tall fescue and cocksfoot cultivars have faster fall regrowth in Mediterranean type climates [38] [40]. Hence, manipulation of the SD trait to improve the sustainability of forage production requires clear understanding of the genetic basis of dormancy, accurate phenotyping, as well as knowledge of the climatic and edaphic environments that control it.

Information regarding genomic features and associated genes controlling the summer dormancy trait is limited. Scientists believe that molecular mechanism of SD comprises several endogenously regulated pathways, which provide the plant genotypes better persistence in dry environment allowing the meristem to remain alive [29] [30] [37]. Molecular studies from three different morphotypes of tall fescue: Continental, Mediterranean, and rhizomatous show that the Mediterranean morphotype is evolutionarily distinct with both the Continental and rhizomatous types, and has different levels of summer dormancy [42] which lead us to believe that summer dormancy variability present in tall fescue germplasms has breeding value.

\subsection{Fall/Winter Dormancy (FD)}

\subsubsection{Fall Dormancy and Winter Hardiness}

Fall dormancy (FD) refers to the slow growth of certain plant species in autumn leading to low height and decumbent shoot growth. Under temperate or continental climates, low temperature is usually the major limitation for the growth of forage plants, and fall/winter dormancy are the main adaptive responses [43]. Unlike summer dormancy, complete senescence and zero growth are common in the fall dormant species. Even though fall dormancy is typical to most $\mathrm{C} 4$ warm season herbaceous species, several C3 perennial species like alfalfa (Medicago sativa L.) evolved fall dormancy as an escape mechanism to protect themselves from cold winter temperatures in the most northern latitudes. 
FD is considered a critical trait that enables alfalfa to survive in climatic zones outside its natural range [44]. Fall dormancy in alfalfa is evaluated through fall regrowth pattern after cutting [45]. FD responses of plants generated from reciprocal cleft grafts between dormant and non-dormant showed that the canopy height is essentially shaped by shoot and crown's genotype [46]. Contrary to the common belief that dormant alfalfa is low yielder, annual average yield of some dormant cultivars showed higher biomass than non-dormant cultivars in their environment of adaptation [http://oregonstate.edu/]. Fairey et al. (1996) described the relationship between North American alfalfa cultivars in terms of their source of germplasm and FD performances [47], which led to the development of 11 FD classes as check cultivars [48]. A significant interaction between location and variety has been found among the 19 tested varieties with 7 FD classes (2 to 8 ) over five locations in China [49]. These extensive phenotypic studies carried in alfalfa make it a suitable model crop for FD studies in herbaceous perennial crops [50]. FD is also common in summer grasses like bermudagrass [51] and influences herbage yield and winter survival of the dormant species.

Winter hardiness $(\mathrm{WH})$ is a complex trait referring to the ability of the plant to survive under sub-optimal winter conditions. Challenges to plants in winter include freezing temperature, diseases, moisture level, snow, and low light intensity [52] [53]. Similarly, cold tolerance simply indicates the plant's ability to survive freezing temperature stress [52]. Understanding the mechanism of WH is critical to grow alfalfa in northern climates (North Central US and Canada) since it influences yield, persistence, survival, and forage quality. $\mathrm{WH}$ is also influenced by physiological and morphological factors such as nutrient ( $\mathrm{C}$ and $\mathrm{N}$ ) and lipid metabolism, cold acclimation potential, plant health and disease, plant root and crown structure as well as the dormancy level of the genotypes [54].

Fall dormancy and winter survival in alfalfa have been considered to be positively correlated traits [55]. Realizing the relationship between fall dormancy and winter survival, several alfalfa-breeding programs use dormancy as a surrogate for winter hardiness and indirectly select for WH by selecting more dormant germplasm [56]. Winterkill in alfalfa stands depends on the extent of the cold that alfalfa roots can withstand as well as the overall hardiness of genotypes [57]. Alfalfa cold hardiness also relies on soil moisture, and the amount of insulation provided to the roots by the soil environments [57]. Recent findings based on genetic analysis suggested that dormancy and cold tolerance are inherited independently and could be analyzed as unlinked traits [44] [54] suggesting that the two traits were carried together through long-term selection.

Even though WH of alfalfa genotypes can be phenotypically predicted to some extent using FD levels, it is affected by other factors. Nitrogen metabolism was found to be associated with the development and maintenance of alfalfa hardiness [58]. Similarly, fertilization in fall affects the cold tolerance of Kentucky bluegrass [59], and autumn mowing also effects the winter survival of love grass 
(Eragrostis cilianensis) [60]. In saltgrass (Distichlis spicata L.), the extent of variation in FD and plant growth is dictated by the environmental conditions in the location of origin of germplasm. Therefore, cold tolerance could be a challenge if the germplasm is moved to climatic regions more northern of their region of adaptation [61]. In the dicot species Flordaking peach tree (Prunus persica), the time and duration of fall defoliation and chilling accumulation correlate with vegetative bud out breaking in spring [62].

\subsubsection{Fall Dormancy Characteristics}

Classifying fall dormancy levels of germplasm and recommending specific niches is an important step for the selection and development of adapted cultivars. Alfalfa is the only herbaceous perennial species where fall dormancy has been characterized. Based on plant regrowth in autumn, there are 11 standard classes of fall dormancy and the classes are assigned based on regression with standard checks [48]. The 11 FD classes are divided into sub-categories: dormant, 1 - 4 FD; semi dormant, 5 - 7; and non-dormant, 8 - 11 [63]. However, defining fall dormancy (FD) classes in alfalfa is time-consuming due to its complexity and the influence of different environmental factors and their interactions. Furthermore, it is imperative to grow the germplasm in the field for at least two years at multiple locations in order to have an accurate estimate of fall dormancy classes [48]. Near infra-red reflectance spectroscopy was evaluated as a potential tool to estimate FD classes in alfalfa [64], but has never been applied in practice. Therefore, identifying associated genes and genomic locations underlying fall dormancy through genetic mapping and developing markers would be very beneficial. The manipulation of dormancy alleles using molecular markers will enable the development of cultivars with an extended growing season.

\subsubsection{Growth Cessation in Winter}

Winter in the temperate regions is usually associated with freezing temperature and low soil moisture. Perennial plant species grown in high latitudes rely on winter dormancy and growth suspension during the cold months for survival and persistence under cold temperatures [9] [65]. Plants have also undergone evolutionary changes in morphology and anatomy to cope with sub optimal growing conditions. Most of the higher trees senesce and undergo defoliation in winter as a mechanism of tolerance and to survive harsh winter conditions. In the United States, almost every state has a historical record of freezing temperature indicating low temperature as one of the major limitation for the growth of forage species in the cold season. Therefore, cold tolerance and winter survival in herbaceous crops are very important considerations for the manipulation of winter dormancy.

\section{Temperature, Photoperiod and Dormancy}

Photoperiod and temperature are major environmental components controlling growth responses in plants [9] [66] [67]. Several studies have indicated the role 
of these two factors in inducing seasonal bud and seed dormancy of crops. Warm season grasses like big bluestem (Andropogon gerardii), indiangrass (Sorghastrum nutans) and switchgrass (Panicum virgatum L.) are photoperiod sensitive, which is under genetic control. Photoperiod requirements for flowering and fall senescence for these species differ depending on latitude of their origin, as in alfalfa [68]. For example, evolution of northern and southern switchgrass ecotypes was shaped by two major factors: length of the growing season and winterkill susceptibility [69]. Therefore, if southern ecotypes are moved to far north, they may not develop full vegetative growth because of insufficient photoperiod during the shorter growth season.

Exposing switchgrass plants to extended photoperiod resulted in increased number of tillers and biomass accumulation [70]. Increased yield was observed in three subtropical forage grasses: bahiagrass, bermudagrass, and star grass (Cynodon nlemfuensis Vanderyst) when exposed to $15 \mathrm{hrs}$. of light instead of natural day length [71]. Ofir and Koller [72] [73] reported induction of dormancy in a perennial grass Hordeum bulbosum L. during early stages of reproductive growth when exposed either to low temperature or short days followed by long days while long days and increased temperature collectively induce summer dormancy in Poa bulbosa L., P. scabrella; Allium cepa L., A. sativum L., Ranunculus spp., and Anemone coronaria L. [74]

Temperature is another factor controlling plant metabolic processes in warm-season grasses, whereby metabolic pathways such as photosynthesis, respiration, and growth processes are catalyzed by enzymes whose activities are affected by temperature. Blue grama (Bouteloua gracilis) flowered in both long and short days when temperature remained fairly high at $75^{\circ} \mathrm{F}$ but failed to flower at lower temperature of $60^{\circ} \mathrm{F}$ [75]. Big bluestem bloomed in short days (10 hours) at a fairly high temperature of $75^{\circ} \mathrm{F}$ during the day and cool temperature of $60^{\circ} \mathrm{F}$ during the night, but did not bloom in this short day when the temperature was kept at $75^{\circ} \mathrm{F}$ throughout. These results indicate that big bluestem is a short-day plant and day-night temperature determines whether it will flower [75]. Temperature used for acclimation in controlled environment fluctuates the level of cold tolerance in perennial ryegrass [43].

Photoperiod and temperature also play notable roles in regulating seed dormancy. Information is scarce regarding seed dormancy studies in forage grasses, however, several reports are available for other grass species like rice (Oryza sativa L.) and eudicots. Research has shown that photoperiod experienced by the seed parent as well as levels of stratification influence the extent and speed of seed germination in Arabidopsis thaliana [76]. Short-day photoperiod was found to be helpful for enhanced germination rates. It was hypothesized that the magnitude of seed germination under certain temperatures might indicate the response of its parent plant in the same environmental condition [76]. In addition, photoperiod used for seed maturation can be a determinant of the seasonal responses of new seeds [76]. Researchers have found that high-dormancy cultivars 
of switchgrass showed low germination rate under a constant, warm temperature $\left(30^{\circ} \mathrm{C}\right)$, however, low-dormancy cultivars show good germination percentage under the same temperature condition [77]. Additionally, germination for both low and high-dormancy cultivars showed similar germination in the dark condition.

\section{Photoperiod, Temperature and Parental Genotype}

Virtually almost all plant genes and genetic factors are photoperiod and temperature responsive. The circadian rhythm in plants responds to the effect of changing photoperiod and light [78]. Genes expressed in seed-parent plant, which is mostly under the control of light and temperature, influence seasonal dormancy of seeds. Maternal control of germination includes thickness of seed coat, endosperm, and hormonal composition in response to light signals [79]. Dormancy and other phenotypic characteristics of seeds are influenced in several ways by the seed-parent's environment [80]. Light and nutrients acquired by the maternal parent can result in bigger seeds with reduced germination percentage [81] and parental environment shapes the genetic variation in the seeds. In a bermudagrass (Cynodon spp. Rich.) cultivar "Tifton419" and Kentucky bluegrass (Poa pratensis L.) cultivar "Midnight II", the levels of sugar and Abscisic acid (ABA) increased and Gibberellic acid (GA) level decreased resulting in the induction of fall dormancy, as a consequence of decreased illumination duration [51]. In Arabidopsis, seeds obtained ABA from maternal tissues [82].

\section{Molecular Mechanisms of Seasonal Dormancy}

\subsection{Genetic Control of Dormancy}

Several plant genes control seasonal dormancy and relaxation (Table 2). Ding and Missaoui (2017) confirmed CONSTANS and TERMINAL FLOWER (TFL), dormancy-associated MADS-box (DAM), auxin response factors (ARFs) and heat shock proteins (HSPs) as potential candidate genes involved in the control of tall fescue summer dormancy (Table 2) [83]. Similarly, SD in a perennial ornamental plant Narcissus tazetta var. Chinensis might be regulated by a gene Narcissus FT gene homologue (NtFT) [84]. In a monocot Lilium longiflorum, $\mathrm{SD}$ is induced by higher temperature and accumulation of $\mathrm{ABA}$, which is under the control of 9-cis-epoxycarotenoid dioxygenase (NCED) gene [85]. Similarly, in grapevine (Vitis vinifera), genes related to growth regulators $\mathrm{ABA}$, auxin, ethylene, and salicylic acid metabolism are involved in regulating summer dormancy and relaxation [86].

Fall dormancy genomic information is expanding due to several studies performed on alfalfa. Some traits related to fall dormancy such as freezing tolerance and cold acclimation were believed to be controlled by $\mathrm{C}$ repeat binding factor (CBF) pathway. The binding of a transcription factor to the $\mathrm{C}$ motif triggers the expression of a cascade of cold-regulated (COR) genes. The expression of these genes helps the plant resist injury when exposed to freezing temperature. 
Table 2. Vegetative and flower bud dormancy related genes in plant.

\begin{tabular}{|c|c|c|c|}
\hline Species & Genes & Characteristics & Sources \\
\hline $\begin{array}{l}\text { Arabidopsis \& } \\
\text { Leafy spurge }\end{array}$ & DAM genes & $\begin{array}{l}\text { Expressed in bud and shoot tips of leafy spurge, delays flowering, associated to } \\
\text { AGAMOUS-LIKE } 24 \text { and SHORT VEGETATIVE PHASE transcription factors. }\end{array}$ & [95] \\
\hline Sorghum & phyB & Photoreceptor, inhibit bud outgrowth & [166] \\
\hline Tall fescue & $\mathrm{CO}, \mathrm{TFL}$ & Meristem determinacy and summer dormancy genes & [83] \\
\hline Tall fescue & ARFs and HSPs & Heat and temperature responsive genes & [83] \\
\hline Peach & bZIP & Transcription factor & [167] \\
\hline Pear & $\begin{array}{l}\text { DAM: PpMADS13-1, } \\
\text { PpMADS13-2 }\end{array}$ & Trigger seasonal dormancy, downregulated with endodormancy & [168] \\
\hline Peach & PpDAM5 and PpDAM6 & DAM genes of peach & [169] \\
\hline Tomato & JOINTLESS & Homologs of SVP of apple, pedicel abscission and bud dormancy & [170] \\
\hline Maize & MADS-box genes & Encode transcription factor, controls flower and inflorescences & [171] \\
\hline Populus & $\mathrm{ABI} 1 \mathrm{~B}$ and $\mathrm{ABI} 3$ & Associated with the ABA & \\
\hline Populus & PHYA & Photoperiod related gene & \\
\hline Kiwifruit & SOC1 & Control dormancy duration & [172] \\
\hline Sorghum & TB1 and MAX2 & $\begin{array}{l}\text { Branching related genes, suppress bud outgrowth, TB1 is controlled by } \\
\text { phytochrome B (phyB) }\end{array}$ & {$[173]$} \\
\hline Pea & DRM1 & Dormancy gene of axillary buds & [174] \\
\hline
\end{tabular}

In addition to CBF and COR genes, cold acclimation specific (CAS) genes cas15 and cas30, along with C-repeat motif and likely CBF-regulated genes, were also reported to be expressed in relation to freezing tolerance [87]. Zhang and Wang (2014) performed transcriptome profiling using RNA-seq analysis and observed differential expression of some potential genes associated with FD in alfalfa [88]. A cold acclimation specific gene, $C A S 18$, from Medicago falcata may have a potential role in alfalfa fall dormancy [89]. Moreover, an allele al from a cold related gene MSAIC B showed correlation with autumn plant regrowth height in the cultivar WISFAL-6 [90]. Recent progress in next generation sequencing enabled the understanding of the genetic basis of complex traits like dormancy. Recently a genotyping-by-sequencing (GBS) based linkage map for fall dormancy of tetraploid alfalfa was reported [91]. The linkage groups identified on autotetraploid $M$. sativa were mostly syntenous with $M$. truncatula.

Although grasses diverged from eudicots millions of years ago [92], they still include conserved homologous and paralogous genes. Thus, analyzing dormancy related genes from other species is valuable to study grass dormancy. Expression analysis based on Real-time PCR showed up-regulation of a carbohydrate metabolism and adventitious bud dormancy gene, beta-amylase gene (Ee-BAM1) in leafy spurge (Euphorbia esula) [93]. Similarly, Saito et al. (2013) examined winter bud dormancy-associated MADS-box (DAM) genes, MADS13, at expressional and structural levels in Japanese pear (Pyrus pyrifolia Nakai) [94]. They observed a low expression of MADS13 genes during endodormancy phase 
transition. The expression of dormancy-associated MADS-box genes (DAM2) has been correlated with endodormancy induction in leafy spurge (Euphorbia esula), and DAM1 overexpression in Arabidopsis delayed flowering (Table 2) [95]. DORMANCY ASSOCIATED MADS-box (DAM) genes, which are closely related to SVP, have been identified to play a role in endodormancy initiation, where expression of DAM genes may be required for down-regulating FT and CENL1 during the endodormancy in some perennial species [96] [97]. Several components of the circadian clock are known to interact with two floral-regulating MADS-box transcription factors in poplar, flowering locus c (FLC) and SHORT VEGETATIVE PHASE (SVP) [98] [99] [100]. These two factors also regulate FT and CENL1 in Arabidopsis [101] [102] [103]. Similarly, other circadian clock genes; late elongated hypocotyl1 (PttLHY1), PttLHY2 and time of cab expression (PtTOC1) are putatively involved in the control of seasonal growth cessation, bud regrowth, and freezing tolerance in Populus [104]. There are multiple pathways linking environmental input signals to dormancy regulation and flowering. In Arabidopsis, phytochromes and cryptochromes perceive photoperiod and temperature signals and are associated with circadian clock [105]. Circadian control involves feedback loop interactions among genes such as CIRCADIAN CLOCK ASSOCIATED1 (CCA1), EARLY FLOWERING 3 - 4 (ELF3 and ELF4), GIGANTIA (GI), LATE ELONGATED HYPOCOTYL (LHY), PHTOCHROME-INTERACTING FACTOR3 (PIF3), PSEUDO-RESPONSE REGULATORS (PRR9, PRR7 and PRR5), TIMING OF CAB1 (TOC1), LUX ARRHYTHMO (LUX) and ZEITLUPE (ZTL) [106] [107].

Cessation of meristem activity in determinate cultivars as result of floral induction might be regulated by a similar process as in the cessation of growth of meristematic cells in seasonal dormancy [108]. Different genes from various crops have been listed as control factors in determinacy of meristem. For instance, the maize ortholog of Arabidopsis terminal flower1 (TFL1) called ZEA CENTRORADIALIS (ZCN1) acts on maize plant meristem indeterminacy, flowering delay, as well as flower architecture [109]. Proteins regulating flowering in Arabidopsis, such as FLOWERING LOCUS T (FT), TERMINAL FLOWER 1 (TFL1), PHYTOCHROME A (PHYA), and CONSTANS (CO), have been associated with growth cessation and endodormancy in poplar [110] [111] [112] [113]. CENTRORADIALIS-LIKE 1 (CENL1), an orthologue of TFL-1 also regulates seasonal growth cessation and dormancy in poplar [110] [112]. The CEN1/ TFL1 gene family also controls flowering [114].

\subsection{Molecular Mechanism of Seed Dormancy}

Seed dormancy refers to the condition where viable seed does not germinate, even in favorable environment [115]. Seed dormancy of grasses has been rigorously researched in the last few decades and scientists hypothesized several evolutionary significances of seed dormancy in grasses. In herbaceous perennial plants, both seed and maternal plant dormancy exist and are probably controlled 
by similar mechanisms [116] [117]. Seed dormancy has been classified into physiological dormancy, morphological dormancy, morpho-physiological dormancy, physical dormancy, and combinational dormancy [118]. For example, seed dormancy in switchgrass has been identified as non-deep physiological dormancy, with the pericarp layer as a major influential factor [119]. Seed germination for switchgrass can be increased by scarification, stratification, and after-ripening period, among others [120]. Burson et al. (2009) indicated that switchgrass seed dormancy controlled by multiple genes and the trait exhibits strong genotype $\mathrm{x}$ environment interaction [121].

Relationship between seed dormancy and seasonal bud dormancy is still a matter of debate. A recent study indicated that seed dormancy may have relationship correlation with seasonal plant dormancy of tall fescue, and seed dormancy could be used as a surrogate phenotype for summer dormancy of the parent genotype [37]. However, Adkins et al. (2002) suggested that seeds of warm season grasses have embryo cover and the embryo itself is the location and origin of dormancy [122]. Several plant genes involved in seed dormancy have been discovered (Table 3). Costa et al. (2015) identified several putative genes such as EARLY RESPONSIVE TO DEHYDRATION 7, LEA14, BXL2, JAZ1 etc. for desiccation tolerance and seed dormancy of Arabidopsis thaliana whose orthologs were also present in other plants such as, $M$. truncatula and $C$. plantagienum and S. stapfianus [123]. They highlighted that desiccation tolerance has co-evolved with seed dormancy sharing common processes that help the plant to adapt to stress environments. Similarly, QTL for rice seed dormancy have been mapped and rice homologues of Arabidopsis seed dormancy genes were also identified [124]. Wheat (Triticum aestivum L.) and barley (Hordeum vulgare L.) reduced seed dormancy causes pre-harvest sprouting resulting in significant yield loss [125]. Barley has two major quantitative traits (QTL) for seed dormancy, SD1 and SD2, on chromosome 5H [125]. Nakamura et al. also reported that mitogen-activated protein kinase cascade regulates seed dormancy in barley [125]. Similarly, Lin et al. (2009) reported seed dormancy QTL in barley [126].

Seed dormancy is a major player in plant population diversification, colonization of new environments, and extinction. Its regulation could evolve with the seed itself [127]. Enhanced seed dormancy was observed in transgenic lines with over-accumulated ABA [128] [129] [130] [131]. This implies that ABA inhibits seed germination and induces dormancy. The role of gibberellin (GA) in triggering germination via countering the effect of $A B A$ is well documented [132]. Various genes involved in the ABA and GA pathways that are known to influence seed dormancy and germination are shown (Figure 1).

\section{Hormonal Control of Seasonal Dormancy}

The major plant hormones ABA, Auxin, GA, ethylene, and cytokinin are vital to almost all plant biological processes. These growth regulators are also necessary for the regulation of vegetative bud, seed, and flower bud initiation, sprouting, 
Table 3. Genes involved in seed germination and seed dormancy of various plant species.

\begin{tabular}{|c|c|c|c|}
\hline Species & Genes & Characteristics & Sources \\
\hline Bromussecalinus & pBS128 & Up-regulated when seed hydrated & {$[175]$} \\
\hline Brachypodium & $\begin{array}{l}\text { BdNCED1, BdNCED2, } \\
\text { BdABA } 8 ₫ O H-1 \text { and BdABA } 8 ₫ O H-2\end{array}$ & ABA synthesis and catabolism & {$[176]$} \\
\hline Barley & $\mathrm{SD} 1, \mathrm{SD} 2$ & Mitogen-activated protein kinase cascade & {$[125]$} \\
\hline Rice & GA20-oxidase & Gibberellic acid (GA) synthesis pathway & [177] \\
\hline Rice & Oryzasativa Sdr4 (OsSdr4) & Seed dormancy and pre-harvest sprouting & {$[115]$} \\
\hline Rice & qSD, qSD12 & $\mathrm{qSD} 12$ promotes $\mathrm{ABA}$ accumulation & {$[178][179]$} \\
\hline 36 different species & $\begin{array}{l}\text { Sdr4 like gene } \\
(S d r 4 L)\end{array}$ & $\begin{array}{l}\text { Gene of Sdr4 gene families and found in Ricinus communis, } \\
\text { Carica papaya, Malus domestica, rice, maize, brachypodium, } \\
\text { setaria, switchgrass, cucumber, bean etc. }\end{array}$ & {$[115]$} \\
\hline Hybrid Leymus & (DRG50) & Seed dormancy and shattering & {$[180]$} \\
\hline Arabidopsis & $\begin{array}{l}\text { DOG1, ABI3, FUSCA3 (FUS3), LEC1 } \\
\text { and LEC2 }\end{array}$ & $\begin{array}{l}\text { DOG1 is quantitative trait locus; } \\
\text { ABI3, FUS3, LEC1 and LEC2 are transcription factors, seed } \\
\text { maturation regulators }\end{array}$ & {$[181]$} \\
\hline $\begin{array}{l}\text { Arabidopsis, Rice, } \\
\text { and Maize }\end{array}$ & VP8/PLA3/GO/AMP1 & Specific effect in seed dormancy & {$[182]$} \\
\hline Arabidopsis & $\begin{array}{l}\text { PYR, PYL/RCAR; ABI1, ABI2, HAB1, } \\
\text { AHG3; KAI1/MAX2 }\end{array}$ & Hormone regulators & {$[182]$} \\
\hline $\begin{array}{l}\text { Wheat and } \\
\text { Arabidopsis }\end{array}$ & MOTHER OF FT AND TFL1 (MFT) & Regulation of germination & {$[183]$} \\
\hline Arabidopsis & SPT, PIL5, AtrbohB, PRT6, ATE & Seed dormancy releasing genes & {$[182]$} \\
\hline Arabidopsis & FLC & MADS-box TF & {$[182]$} \\
\hline Arabidopsis & $\mathrm{CBF}$ & Cold response pathway & {$[182]$} \\
\hline Arabidopsis & $\begin{array}{l}\text { HUB1, HUB2; RDO2; VIP4, VIP5, ELF7, } \\
\text { ELF8, ATXR7; EFS; FIE and KYP/SUVH4, } \\
\text { SUVH5 }\end{array}$ & Epigenetic regulators of seed dormancy & {$[182]$} \\
\hline Arabidopsis & LHY, CCA1, GI, ZTL, and LUX & Circadian clock genes & {$[184]$} \\
\hline
\end{tabular}

and dormancy. $\mathrm{ABA}$ is involved in plant storage deposition, prevention of pre-harvest sprouting, dehydration tolerance, and dormancy induction at early stage. Transcription factors like ABI3/VP1, ABI4, ABI5, LEC1, LEC2, and FUS3 are involved in ABA signaling and production [133]. The genes from CYP707A gene family are also associated with ABA levels in Arabidopsis seeds [128]. ABA also induces summer dormancy in Poa bulbosa [134] and its level in the plant changes under dehydrated conditions [135]. ABA controls bud dormancy in grapes where its level increases in autumn and its metabolism is modified by the stimuli of dormancy release [136].

Hormonal activity is associated with plant dormancy in several ways. Summer dormancy in Poa bulbosa is induced by long day photoperiod or by water deficit, and both situations show increase in ABA levels [74]. ABA counteracts the role of Auxin for apical dominance when it is applied to decapitated shoots in 


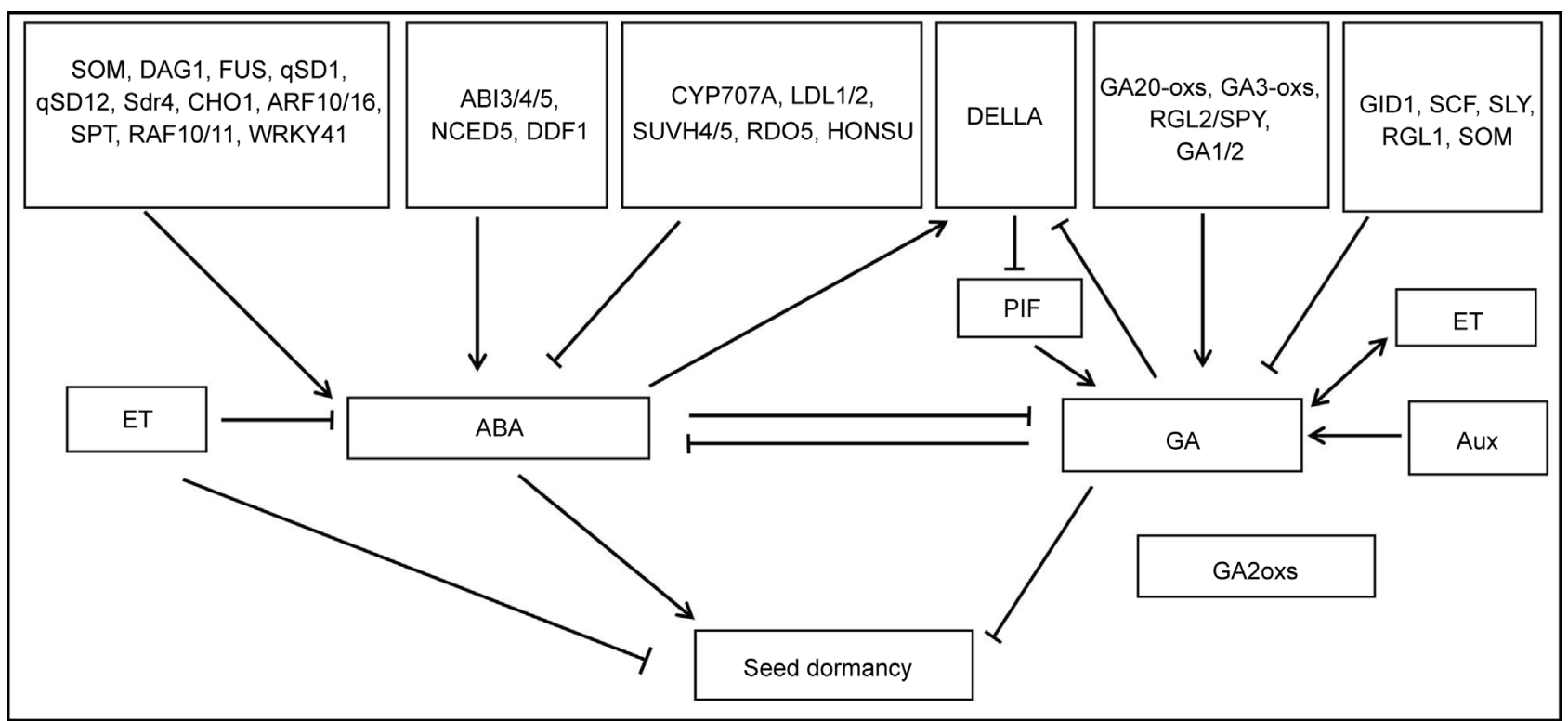

Figure 1. Schematic diagram showing the effect of major hormones and some important genes in seed dormancy of plants. The symbol " $\rightarrow$ " indicates the up regulation and “ $\longmapsto$ " indicates negative effect to the resulting components or processes [185] [186].

Ipomoea nil, Solanum lycopersicum and Helianthus annus [137]. In the case of physiological dormancy, the level of ABA increases and that of gibberellin and cytokinin decreases [138] [139]. Mohapatra et al. (1988) studied the effect of ABA induction in freezing tolerance in alfalfa [140] and observed ABA regulation of some gene expression during cold acclimation. Most researchers believe that the physiological mechanisms that control the transition between dormancy and germination are hormonal in nature [141] [142]. The balance between ABA and gibberellic acid (GA) is also important in this process. GA promotes germination [120] [143] while ABA induces and maintains dormancy [144] [145]. The embryo produces $\mathrm{ABA}$ when the seed is developed in the mother plant, which can control dormancy and germination through the endogenous concentration and seed sensitivity [146] [147]. However, with exogenous ABA application, germination decreased. In hybrid aspen (Populustremula $\times$ tremulö̈des), proper distribution of GA in vascular tissue is essential to trigger auxin for flowering and bud outgrowth [148].

In the tree peony (Paeonia suffruticosa) the accumulation of ABA and sugars in winter might induce the dormancy [149]. Further, GA accumulation and degradation of $\mathrm{ABA}$ in spring releases bud dormancy, and temperature becomes the major controlling factor in hormonal regulation. Application of GA impacts positively the post-harvest longevity of grass like Miscanthus sinensis [150]. However, gibberellin inhibits growth in mild dehydration condition, similar to ethylene [135]. Alfalfa roots contain variable amounts of GA3, indole-3-acetic acid (IAA), and ABA depending on their fall dormancy levels [151] and these endogenous hormones play, at least, a partial role in spring regrowth variation in alfalfa. 
Zhuang et al. (2015) described the transcriptomic and metabolic changes brought by GA treatment on the release of flower bud dormancy in Japanese Apricot (Prunus mume) [152]. Cytokinin was found to be essential for meristem activity in potato tubers [153]. Auxin plays a role in shoot branching, bud outgrowth, and dormancy [154]. Other auxin responsive genes control growth and are involved in most of the aspects of plant growth and development [155]. Changing levels of ARR5::GUS activity in Populus $\times$ canescens indicated that change in the concentration of cell and tissue specific cytokinin in winter and summer leads to variability in dormancy and sprouting [156].

\section{Breeding for Seasonal Dormancy}

Genetic variation in germplasm, accurate phenotyping, and genotyping are essential components for successful selection. There is a limited availability of germplasm of herbaceous perennial species that has been well characterized for summer, fall, and winter dormancy in order to manipulate the trait. An exception is alfalfa fall dormancy where several dormant, semi dormant and nondormant checks and commercial cultivars are available. Since alfalfa fall dormancy may be associated with winter hardiness, we can use phenotypic data of cold hardiness to indirectly select for dormancy and vice-versa. Various reports showed a close connection between winter hardiness and accumulation of raffinose and stachyose in roots and crowns [157], which might be valuable information to the study of FD. Exploitation of indoor selection methods as a reliable phenotyping process to freezing tolerance of alfalfa are also described [158], and could be useful in the prediction of FD in alfalfa. Consecutive cycles of recurrent selection coupled with indoor screening have been suggested as a suitable approach to develop freezing tolerant alfalfa [159]. Although most of the grasses are allogamous, still some species show pseudo self-compatibility such as switchgrass [160], and the characteristic could be useful for breeding semi-dormant cultivars. Germplasm sources for bermudagrass fall dormancy and winter hardiness studies include all released cultivars and natural wild germplasms [15]. Similarly, other studies indicated that the continental type and Mediterranean type tall fescues could be valuable sources for summer dormancy breeding since most of them show variability in dormancy. Ding and Missaoui (2016) showed that seed dormancy and germination at low and high temperature of tall fescue could be used as a surrogate phenotype to determine summer dormancy of the plant itself [37].

\section{Genomic Resources for Seasonal Dormancy}

Clear understanding of the molecular pathways and genetic basis governing plant growth responses to seasonal changes in herbaceous perennial species is still lacking. However, various functional genomics, statistical, and bioinformatics tools available today are conducive to study genetic traits of interest in herbaceous perennial species. Phytozome genomics portal, for example, enables the 
study of seasonal dormancy of herbaceous plants and their genetic and genomics values, using the structure of annotated genes, protein homologs, gene ancestry, and expression [161]. The orthologs of vegetative bud dormancy genes in Brachypodium distachyon found a leucine zipper (bZIP) transcription factor at locus Bradilg17210 as an associated gene (Figure 2). Blast search (BlastX) for the other related plant proteins in Jbrowse (Figure 3) which can be linked from the same portal page, returned related proteins in Sorghum bicolor, Oropetium Zeamays etc. (Figure 3). The transcription factor bZIP is one of the highly conserved plant genes controlling several biological processes such as seed and flower development [162]. Seed germination control by ABI5, a bZIP gene, supports the involvement of this transcription factor in dormancy. Therefore, comparative genomics approaches may enable the use of information from woody plants to find out homologous and paralogous genes associated with seasonal dormancy in herbaceous perennials.

Blast $2 \mathrm{GO}$ is another comprehensive suite for functional analysis of plant genomics and it provides a universal tool for annotation, visualization, and analysis. Based on gene ontology vocabulary, it optimizes function transfer from homologous sequences [163]. The comparative genomics platform CoGe (http://www.genomevolution.org) which is available through iPlant Collaborative [164] can used to analyze and compare various genomes. It is a web-based system that provides more than 30 interconnected applications to analyze, compare, and visualize nearly 20,000 genomes with tools like single gene, multiple gene, whole genome, multiple-genome as well as synteny analyses [165].

\section{Conclusions}

Seasonal dormancy in herbaceous perennial grasses and legumes is an adaptive

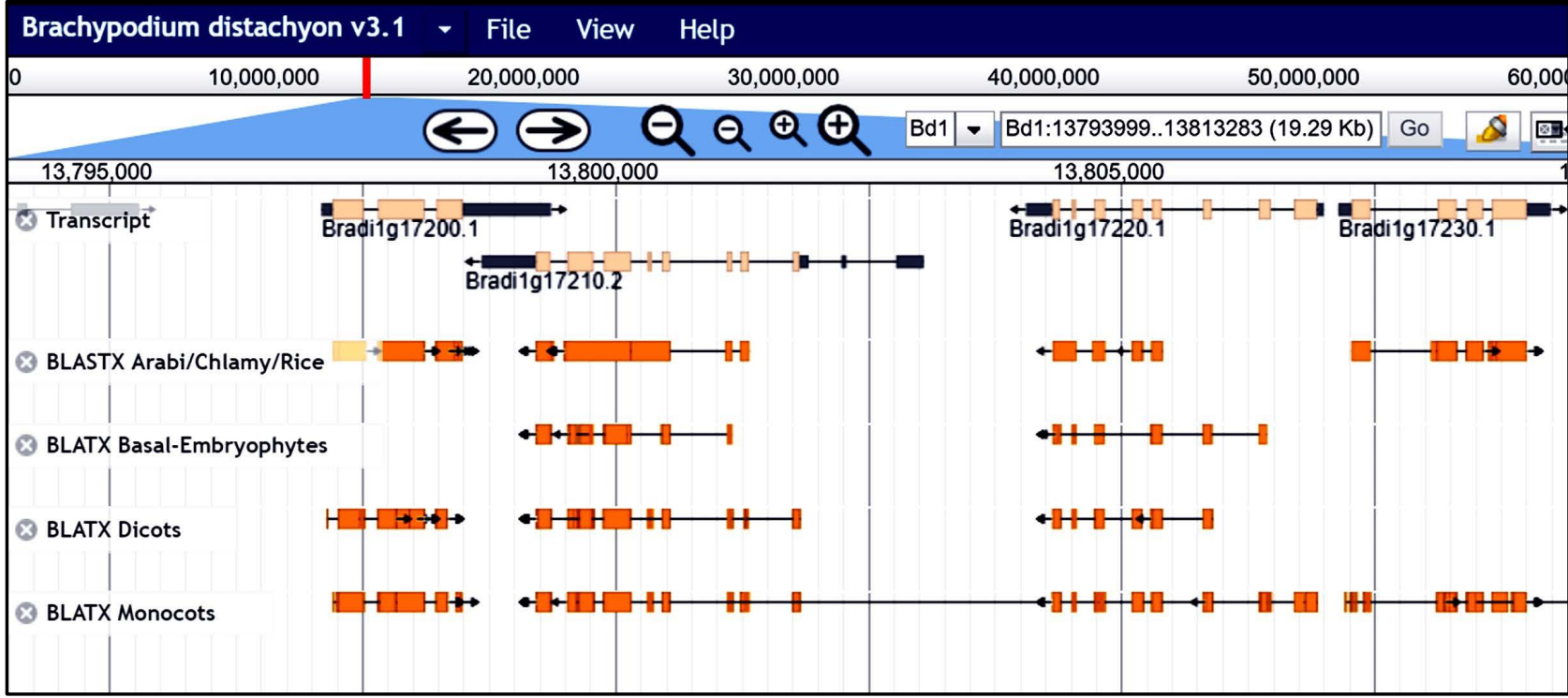

Figure 2. Structure of Brachypodium distachyon bud dormancy related gene, leucine zipper (bZIP), obtained using JBrowse of Phytozome 12.1 portal (https://phytozome.jgi.doe.gov). 


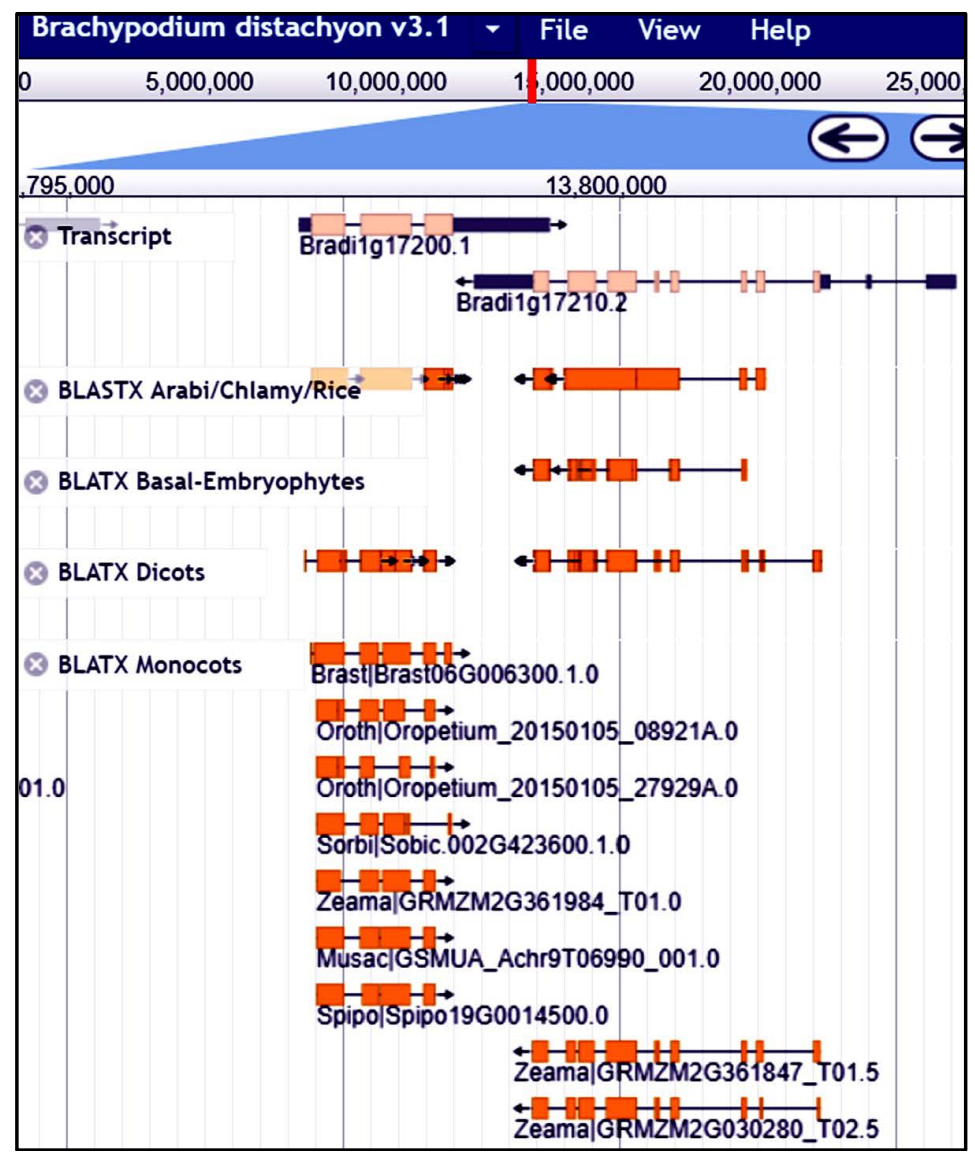

Figure 3. Brachypodium distachyon bZIP gene and related proteins in other organisms: Oropetium, Zeamays, Sorghum bicolor etc. viewed in JBrowse of Phytozome 12.1 portal (https://phytozome.jgi.doe.gov/jbrowse).

mechanism to survive in harsh environments. It can be manipulated through conventional selection and breeding, and using genomics to increase the growing season and crop yield. Weather extremes in summer and winter challenge herbage production. Improving forage production through dormancy manipulation to extend the growing season would be economically profitable. There is available germplasm for breeding species like alfalfa, bermudagrass, and tall fescue that can be exploited to develop non-dormant cultivars. Furthermore, knowledge of genes and genomic features controlling eudicots could be applicable to improve herbaceous forages, although they are evolutionarily divergent. Technological advances in genotyping, genomic selection, and high throughput phenotyping will play an important role in future dormancy related studies. This review summarizes important updates for plant dormancy related studies and the information could be useful to manipulate seasonal dormancy to develop non-dormant and semi-dormant cultivars that can overcome forage shortage in off seasons.

\section{References}

[1] Bayer, W. and Waters Bayer, A. (1998) Forage Husbandry. Macmillan. 
[2] Bouton, J. (2007) The Economic Benefits of Forage Improvement in the United States. Euphytica, 154, 263-270. https://doi.org/10.1007/s10681-006-9220-6

[3] Peters, M., et al. (2001) The Role of Forages in Reducing Poverty and Degradation of Natural Resources in Tropical Production Systems: Overseas Development Institute (ODI). Agricultural Research \& Extension Network (AgREN).

[4] Wedin, W. (1974) 5 Fertilization of Cool-Season Grasses.

[5] Newman, P.R. and Moser, L.E. (1988) Seedling Root Development and Morphology of Cool-Season and Warm-Season Forage Grasses. Crop Science, 28, 148-151. https://doi.org/10.2135/cropsci1988.0011183X002800010032x

[6] Moser, L.E. and Hoveland, C.S. (1996) 1 Cool-Season Grass Overview.

[7] Hsu, F.H., Nelson, C.J. and Matches, A.G. (1985) Temperature Effects on Germination of Perennial Warm-Season Forage Grasses1. Crop Science, 25. https://doi.org/10.2135/cropsci1985.0011183X002500020005x

[8] Lang, G.A., et al. (1987) Endodormancy, Paradormancy, and Ecodormancy-Physiological Terminology and Classification for Dormancy Research. Hortscience, 22, 371-377.

[9] Vegis, A. (1964) Dormancy in Higher Plants. Annual Review of Plant Physiology, 15, 185-224. https://doi.org/10.1146/annurev.pp.15.060164.001153

[10] Kigel, J., et al. (2009) Physiology of Induction and Relaxation of Summer Dormancy in Perennial Grasses. In: Proceedings from the Workshop on Summer Dormancy in Grasses, The Samuel Roberts Noble Foundation, Ardmore.

[11] Volaire, F. and Norton, M. (2006) Summer Dormancy in Perennial Temperate Grasses. Annals of Botany, 98, 927-933. https://doi.org/10.1093/aob/mcl195

[12] Perry, M.C., et al. (1987) Genetic Analysis of Cold Hardiness and Dormancy in Alfalfa. Genome, 29, 144-149. https://doi.org/10.1139/g87-024

[13] Fransen, S., Collins, H. and Boydston, R. (2006) Perennial Warm-Season Grasses for Biofuels. Symposium Proceedings, Western Alfalfa and Forage Conference.

[14] Mislevy, P., Sinclair, T. and Ray, J. (2001) Extended Daylength to Increase Fall/Winter Yields of Warm-Season Perennial Grasses. Proceedings of International Grassland Congress, Sao Pedro, 11-12.

[15] Fagerness, M.J. and Yelverton, F.H. (2000) Tissue Production and Quality of "Tifway" Bermudagrass as Affected by Seasonal Application Patterns of Trinexapac-Ethyl. Crop Science, 40, 493-497. https://doi.org/10.2135/cropsci2000.402493x

[16] Yunfei, Y. and Ling, Z. (1994) Analysis of Winter Dormancy Characters of Vegetadve Forms in Fifteen Perennial Grass Species Populations in Songnen Plain of China. Acta Pratacultural Science, 2.

[17] Bielenberg, D.G. (2015) Comparing Genetic Mechanisms of Bud Chilling Fulfillment and Seed Cold Stratification: A Role for Peach (Prunus persica)? Advances in Plant Dormancy, 257-265. https://doi.org/10.1007/978-3-319-14451-1_15

[18] Rohde, A. and Bhalerao, R.P. (2007) Plant Dormancy in the Perennial Context. Trends in Plant Science, 12, 217-223.

[19] Rees, A.R. (1992) Ornamental Bulbs, Corms and Tubers. CAB International, Wallingford.

[20] Rao, S., Coleman, S. and Volesky, J. (2000) Yield and Quality of Wheat, Triticale, and Elytricum Forage in the Southern Plains. Crop Science, 40, 1308-1312.

https://doi.org/10.2135/cropsci2000.4051308x 
[21] Rao, S.C., Northup, B.K. and Mayeux, H.S. (2005) Candidate Cool-Season Legumes for Filling Forage Deficit Periods in the Southern Great Plains. Crop Science, 45, 2068-2074. https://doi.org/10.2135/cropsci2005.0019

[22] Rao, S.C., Akers, S.W. and Ahring, R.M. (1987) Priming Brassica Seed to Improve Emergence under Different Temperatures and Soil Moisture Conditions. Crop Science, 27, 1050-1053. https://doi.org/10.2135/cropsci1987.0011183X002700050045x

[23] Norton, M. (2010) Summer Dormancy in Temperate Forage Plants. http://www.dpi.nsw.gov.au/_data/assets/pdf_file/0004/412636/summer-dormancyfactsheet181011.pdf

[24] Laude, H.M. (1953) The Nature of Summer Dormancy in Perennial Grasses. Botanical Gazette, 114, 284-292. https://doi.org/10.1086/335770

[25] Ofir, M. and Kerem, D. (1982) The Effects of Temperature and Photoperiod on the Onset of Summer Dormancy in Poa bulbosa L. Annals of Botany, 50, 259-264. https://doi.org/10.1093/oxfordjournals.aob.a086363

[26] Oram, R. (1983) Ecotypic Differentiation for Dormancy Levels in Oversummering Buds of Phalaris aquatica L. Botanical Gazette, 144, 544-551. https://doi.org/10.1086/337409

[27] Volaire, F. and Thomas, H. (1995) Effects of Drought on Water Relations, Mineral Uptake, Water-Soluble Carbohydrate Accumulation and Survival of Two Contrasting Populations of Cocksfoot (Dactylis glomerata L.). Annals of Botany, 75, 513-524. https://doi.org/10.1006/anbo.1995.1053

[28] Ofir, M. and Kigel, J. (2003) Variation in Onset of Summer Dormancy and Flowering Capacity along an Aridity Gradient in Poa bulbosa L., a Geophytic Perennial Grass. Annals of Botany, 91, 391-400. https://doi.org/10.1093/aob/mcg026

[29] Shaimi, N., et al. (2009) Summer Dormancy and Drought Survival of Moroccan Ecotypes of Orchardgrass. Crop Science, 49, 1416-1424. https://doi.org/10.2135/cropsci2008.09.0545

[30] Norton, M.R., et al. (2008) Measurement of Summer Dormancy in Temperate Perennial Pasture Grasses. Australian Journal of Agricultural Research, 59, 498-509. https://doi.org/10.1071/AR07343

[31] Volaire, F., et al. (2009) Water Deficit and Induction of Summer Dormancy in Perennial Mediterranean Grasses. Annals of Botany, 103, 1337-1346.

https://doi.org/10.1093/aob/mcp080

[32] Biddiscombe, E., Rogers, A. and Maller, R. (1977) Summer Dormancy, Regeneration and Persistence of Perennial Grasses in South-Western Australia. Animal Production Science, 17, 795-801. https://doi.org/10.1071/EA9770795

[33] Norton, M., Volaire, F. and Lelievre, F. (2006) Summer Dormancy in Festuca arundinacea Schreb.; the Influence of Season of Sowing and a Simulated Mid-Summer Storm on Two Contrasting Cultivars. Crop and Pasture Science, 57, 1267-1277. https://doi.org/10.1071/AR06082

[34] Volaire, F., Conejero, G. and Lelievre, F. (2001) Drought Survival and Dehydration Tolerance in Dactylis glomerata and Poa bulbosa. Australian Journal of Plant Physiology, 28, 743-754.

[35] Ofir, M. and Kigel, J. (1999) Photothermal Control of the Imposition of Summer Dormancy in Poa bulbosa, a Perennial Grass Geophyte. Physiologia Plantarum, 105, 633-640. https://doi.org/10.1034/j.1399-3054.1999.105406.x 
[36] Ofir, M., Koller, D. and Negbi, M. (1967) Studies on Physiology of Regeneration Buds of Hordeum Bulbosum. Botanical Gazette, 128, 25. https://doi.org/10.1086/336378

[37] Ding, R. and Missaoui, A. (2016) Phenotyping Summer Dormancy in Tall Fescue: Establishment of a Surrogate Phenotype and a Dormancy Rating System in Humid Environments. Crop Science, 56, 2579-2593. https://doi.org/10.2135/cropsci2016.02.0092

[38] Norton, M., Lelievre, F. and Volaire, F. (2006) Summer Dormancy in Dactylis glomerata L.: The Influence of Season of Sowing and a Simulated Mid-Summer Storm on Two Contrasting Cultivars. Crop and Pasture Science, 57, 565-575. https://doi.org/10.1071/AR05237

[39] Volaire, F., et al. (2005) Seasonal Patterns of Growth, Dehydrins and Water-Soluble Carbohydrates in Genotypes of Dactylis glomerata Varying in Summer Dormancy. Annals of Botany, 95, 981-990. https://doi.org/10.1093/aob/mcil02

[40] Malinowski, D., et al. (2005) Obligatory Summer-Dormant Cool-Season Perennial Grasses for Semiarid Environments of the Southern Great Plains. Agronomy Journal, 97, 147-154. https://doi.org/10.2134/agronj2005.0147

[41] Nielsen-Gammon, J.W., et al. (2005) Extreme Rainfall in Texas: Patterns and Predictability. Physical Geography, 26, 340-364. https://doi.org/10.2747/0272-3646.26.5.340

[42] Hand, M.L., et al. (2010) Evolutionary History of Tall Fescue Morphotypes Inferred from Molecular Phylogenetics of the Lolium-Festuca Species Complex. BMC Evolutionary Biology, 10, 1. https://doi.org/10.1186/1471-2148-10-303

[43] Eagles, C.F. (1989) Temperature-Induced Changes in Cold Tolerance of Lolium perenne. The Journal of Agricultural Science, 113, 339-347. https://doi.org/10.1017/S0021859600070027

[44] Brummer, E.C., Shah, M.M. and Luth, D. (2000) Reexamining the Relationship between Fall Dormancy and Winter Hardiness in Alfalfa. Crop Science, 40, 971-977. https://doi.org/10.2135/cropsci2000.404971x

[45] Sprague, M. and Fuelleman, R. (1941) Measurements of Recovery after Cutting and Fall Dormancy of Varieties and Strains of Alfalfa, Medicago sativa. Journal of the American Society of Agronomy. https://doi.org/10.2134/agronj1941.00021962003300050006x

[46] Heichel, G. and Henjum, K. (1990) Fall Dormancy Response of Alfalfa Investigated with Reciprocal Cleft Grafts. Crop Science, 30, 1123-1127. https://doi.org/10.2135/cropsci1990.0011183X003000050033x

[47] Fairey, D., Fairey, N. and Lefkovitch, L. (1996) The Relationship between Fall Dormancy and Germplasm Source in North American Alfalfa Cultivars. Canadian Journal of Plant Science, 76, 429-433. https://doi.org/10.4141/cjps96-076

[48] Teuber, L., et al. (1998) Fall Dormancy. In Standard Tests to Characterize Alfalfa Cultivars. 36th North American Alfalfa Improve Conference, Bozeman.

[49] Xu, G.-M., et al. (2012) Performance of Alfalfa Varieties with Different Fall Dormancy across Different Production Areas of Henan Province of China. African Journal of Agricultural Research, 7, 6197-6203. https://doi.org/10.5897/AJAR12.644

[50] Ariss, J.J. and Vandemark, G.J. (2007) Assessment of Genetic Diversity among Nondormant and Semidormant Alfalfa Populations using Sequence-Related Amplified Polymorphisms. Crop Science, 47, 2274-2284.

https://doi.org/10.2135/cropsci2006.12.0782 
[51] Wang, L., et al. (2014) Dormancy Inducing Mechanisms in Turfgrass. Journal of Food, Agriculture \& Environment, 12, 1182-1184.

[52] McKenzie, J.S., Paquin, R. and Duke, S.H. (1988) Cold and Heat Tolerance. In: Hanson, A.A., Barnes, D.K. and Hill, R.R., Eds., Alfalfa and Alfalfa Improvement, American Society of Agronomy, Crop Science Society of America, Soil Science Society of America, Madison, 259-302.

[53] Waldron, B., et al. (1998) Controlled Freezing as an Indirect Selection Method for Field Winter Hardiness in Turf-Type Perennial Ryegrass. Crop Science, 38, 811-816. https://doi.org/10.2135/cropsci1998.0011183X003800030032x

[54] Brouwer, D.J., Duke, S.H. and Osborn, T.C. (2000) Mapping Genetic Factors Associated with Winter Hardiness, Fall Growth, and Freezing Injury in Autotetraploid Alfalfa. Crop Science, 40, 1387-1396. https://doi.org/10.2135/cropsci2000.4051387x

[55] Cunningham, S.M., et al. (2001) Winter Hardiness, Root Physiology, and Gene Expression in Successive Fall Dormancy Selections from "Mesilla" and "CUF 101" Alfalfa. Crop Science, 41, 1091-1098. https://doi.org/10.2135/cropsci2001.4141091x

[56] Schwab, P.M., Barnes, D.K. and Sheaffer, C.C. (1996) The Relationship between Field Winter Injury and Fall Growth Score for 251 Alfalfa Cultivars. Crop Science, 36, 418-426. https://doi.org/10.2135/cropsci1996.0011183X003600020034x

[57] Weimer, J. (1929) Some Factors Involved in the Winter-Killing of Alfalfa. Journal of Agricultural Research, 39, 263-283.

[58] Jung, G.A., Shih, S.C. and Shelton, D.C. (1967) Seasonal Changes in Soluble Protein, Nucleic Acids, and Tissue pH Related to Cold Hardiness of Alfalfa. Cryobiology, 4, 11-16.

[59] Wilkinson, J.F. and Duff, D.T. (1972) Effects of Fall Fertilization on Cold Resistance, Color, and Growth of Kentucky Bluegrass. Agronomy Journal, 64, 345-348. https://doi.org/10.2134/agronj1972.00021962006400030027x

[60] Voigt, P.W. (1975) Effect of Fall Mowing on Winter Survival of Lovegrass Strains. Crop Science, 15, 574-577. https://doi.org/10.2135/cropsci1975.0011183X001500040036x

[61] Rukavina, H., Hughes, H. and Johnson, R. (2008) Variation in Saltgrass Growth and Time of Fall Dormancy Related to Geographical and Climatic Factors. Journal of the American Society for Horticultural Science, 133, 127-132.

[62] Gariglio, N., et al. (2012) Chemicals Applied in Fall and Defoliation on Dormancy Evolution and Release in Low-Chill Peach "Flordaking". Agrociencia (Montevideo), 16, 49-59.

[63] Zhang, S., et al. (2015) De Novo Characterization of Fall Dormant and Nondormant Alfalfa (Medicago sativa L.) Leaf Transcriptome and Identification of Candidate Genes Related to Fall Dormancy. PLoS ONE, 10. https://doi.org/10.1371/journal.pone.0122170

[64] Kallenbach, R.L., et al. (2001) Estimation of Fall Dormancy in Alfalfa by Near Infrared Reflectance Spectroscopy. Crop Science, 41, 774-777. https://doi.org/10.2135/cropsci2001.413774x

[65] Bélanger, G., et al. (2006) Winter Damage to Perennial Forage Crops in Eastern Canada: Causes, Mitigation, and Prediction. Canadian Journal of Plant Science, 86, 33-47. https://doi.org/10.4141/P04-171

[66] Tanino, K.K., et al. (2010) Temperature-Driven Plasticity in Growth Cessation and Dormancy Development in Deciduous Woody Plants: A Working Hypothesis Suggesting How Molecular and Cellular Function Is Affected by Temperature during Dormancy Induction. Plant Molecular Biology, 73, 49-65. https://doi.org/10.1007/s11103-010-9610-y 
[67] Olsen, J.E. (2010) Light and Temperature Sensing and Signaling in Induction of Bud Dormancy in Woody Plants. Plant Molecular Biology, 73, 37-47. https://doi.org/10.1007/s11103-010-9620-9

[68] Moser, L.E. and Vogel, K.P. (1995) Switchgrass, Big Bluestem, and Indiangrass. Forages, 1, 409-420.

[69] Newell, L. (1968) Effects of Strain Source and Management Practice on Forage Yields of Two Warm-Season Prairie Grasses. Crop Science, 8, 205-210. https://doi.org/10.2135/cropsci1968.0011183X000800020022x

[70] Van Esbroeck, G.A., Hussey, M.A. and Sanderson, M.A. (2004) Reversal of Dormancy in Switchgrass with Low-Light Photoperiod Extension. Bioresource Technology, 91, 141-144.

[71] Sinclair, T.R., Mislevy, P. and Ray, J.D. (2001) Short Photoperiod Inhibits Winter Growth of Subtropical Grasses. Planta, 213, 488-491.

https://doi.org/10.1007/s004250100611

[72] Ofir, M. and Koller, D. (1972) Kinetic Analysis of the Relationships between Flowering and Initiation of the Dormant State in Hordeum bulbosum L. Perennial Grass. Israel Journal of Botany, 21, 21-34.

[73] Ofir, M. and Koller, D. (1974) Relationship between Thermoinduction and Photoinduction of Flowering and Dormancy in Hordeum bulbosum L., a Perennial Grass. Functional Plant Biology, 1, 259-270.

[74] Ofir, M. and Kigel, J. (2007) Regulation of Summer Dormancy by Water Deficit and ABA in Poa bulbosa Ecotypes. Annals of Botany, 99, 293-299. https://doi.org/10.1093/aob/mcl257

[75] Benedict, H. (1940) Effect of Day Length and Temperature on the Flowering and Growth of Four Species of Grasses. Journal of Agricultural Research, 61, 661-671.

[76] Munir, J., et al. (2001) The Effect of Maternal Photoperiod on Seasonal Dormancy in Arabidopsis thaliana (Brassicaceae). American Journal of Botany, 88, 1240-1249. https://doi.org/10.2307/3558335

[77] Duclos, D.V., Altobello, C.O. and Taylor, A.G. (2014) Investigating Seed Dormancy in Switchgrass (Panicum virgatum L.): Elucidating the Effect of Temperature Regimes and Plant Hormones on Embryo Dormancy. Industrial Crops and Products, 58, 148-159.

[78] Salome, P.A., Xie, Q. and McClung, C.R. (2008) Circadian Timekeeping during Early Arabidopsis Development. Plant Physiology, 147, 1110-1125. https://doi.org/10.1104/pp.108.117622

[79] Botto, J.F., Sanchez, R.A. and Casal, J.J. (1995) Role of Phytochrome-B in the Induction of Seed-Germination by Light in Arabidopsis-Thaliana. Journal of Plant Physiology, 146, 307-312.

[80] Donohue, K. and Schmitt, J. (1998) Maternal Environmental Effects in Plants-Adaptive Plasticity? In: Mousseau, T.A. and Fox, C.W., Eds., Maternal Effects as Adaptations, Oxford University Press, Oxford, 137-158.

[81] Marshall, D. and Uller, T. (2007) When Is a Maternal Effect Adaptive? Oikos, 116, 1957-1963. https://doi.org/10.1111/j.2007.0030-1299.16203.x

[82] Karssen, C.M., et al. (1983) Induction of Dormancy during Seed Development by Endogenous Abscisic-Acid-Studies on Abscisic-Acid Deficient Genotypes of Arabidopsis-Thaliana (L) Heynh. Planta, 157, 158-165.

https://doi.org/10.1007/BF00393650 
[83] Ding, R. and Missaoui, A.M. (2017) Candidate Gene Association with Summer Dormancy in Tall Fescue. Euphytica, 3, 1-22. https://doi.org/10.1007/s10681-016-1810-3

[84] Feng, Y., et al. (2015) Characterization of Summer Dormancy in Narcissus tazetta var. Chinensis and the Role of NtFTs in Summer Dormancy and Flower Differentiation. Scientia Horticulturae, 183, 109-117.

[85] Narges, M., et al. (2015) Molecular Cloning and Expression of a 9-cis-epoxy Carotenoid Dioxygenase Gene (NCED) and Its Relationship to Dormancy in Lilium longiflorum and L. Formosanum. Journal of Horticultural Science \& Biotechnology, 90, 121. https://doi.org/10.1080/14620316.2015.11513162

[86] Sudawan, B., et al. (2016) Hydrogen Cyanamide Breaks Grapevine Bud Dormancy in the Summer through Transient Activation of Gene Expression and Accumulation of Reactive Oxygen and Nitrogen Species. BMC Plant Biology, 16, 202. https://doi.org/10.1186/s12870-016-0889-y

[87] Li, X., et al. (2015) Mapping Fall Dormancy and Winter Injury in Tetraploid Alfalfa. Crop Science, 55, 1995-2011. https://doi.org/10.2135/cropsci2014.12.0834

[88] Zhang, S. and Wang, C. (2014) Transcriptome Profiling of Gene Expression in Fall Dormant and Nondormant Alfalfa. Genomics Data, 2, 282-284.

[89] Wolfraim, L.A., et al. (1993) cDNA Sequence, Expression, and Transcript Stability of a Cold Acclimation-Specific Gene, cas18, of Alfalfa (Medicago falcata) Cells. Plant Physiology, 101, 1275-1282. https://doi.org/10.1104/pp.101.4.1275

[90] Alarcón Zúñiga, B., et al. (2004) Quantitative Trait Locus Mapping of Winter Hardiness Metabolites in Autotetraploid Alfalfa (M. sativa). Molecular Breeding of Forage and Turf. Proceedings of the 3 rd International Symposium, Molecular Breeding of Forage and Turf, Dallas, Texas, and Ardmore, Oklahoma, 18-22 May 2003, 97-104. https://doi.org/10.1007/1-4020-2591-2_9

[91] Li, X., et al. (2014) A Saturated Genetic Linkage Map of Autotetraploid Alfalfa ( $\mathrm{Me}$ dicago sativa L.) Developed using Genotyping-by-Sequencing Is Highly Syntenous with the Medicago truncatula Genome. G3: Genes/Genomes/Genetics, 4, 1971-1979. https://doi.org/10.1534/g3.114.012245

[92] Kellogg, E.A. (2001) Evolutionary History of the Grasses. Plant Physiology, 125, 1198-1205. https://doi.org/10.1104/pp.125.3.1198

[93] Chao, W.S. and Serpe, M.D. (2010) Changes in the Expression of Carbohydrate Metabolism Genes during Three Phases of Bud Dormancy in Leafy Spurge. Plant Molecular Biology, 73, 227-239. https://doi.org/10.1007/s11103-009-9568-9

[94] Saito, T., et al. (2013) Expression of Genomic Structure of the Dormancy-Associated MADS Box Genes MADS13 in Japanese Pears (Pyrus pyrifolia Nakai) That Differ in Their Chilling Requirement for Endodormancy Release. Tree Physiology, 33, 654-667. https://doi.org/10.1093/treephys/tpt037

[95] Horvath, D.P., et al. (2010) Characterization, Expression and Function of Dormancy Associated Mads-Box Genes from Leafy Spurge. Plant Molecular Biology, 73, 169-179. https://doi.org/10.1007/s11103-009-9596-5

[96] Horvath, D.P., et al. (2008) Transcriptome Analysis Identifies Novel Responses and Potential Regulatory Genes Involved in Seasonal Dormancy Transitions of Leafy Spurge (Euphorbia esula L.). BMC Genomics, 9, 1.

https://doi.org/10.1186/1471-2164-9-536

[97] Horvath, D. (2009) Common Mechanisms Regulate Flowering and Dormancy. Plant Science, 177, 523-531. 
[98] Fujiwara, S., et al. (2008) Circadian Clock Proteins LHY and CCA1 REGULATE SVP Protein Accumulation to Control Flowering in Arabidopsis. The Plant Cell, 20, 2960-2971. https://doi.org/10.1105/tpc.108.061531

[99] Michaels, S.D. (2009) Flowering Time Regulation Produces Much Fruit. Current Opinion in Plant Biology, 12, 75-80.

[100] Salathia, N., et al. (2006) Flowering Locus C-Dependent and -Independent Regulation of the Circadian Clock by the Autonomous and Vernalization Pathways. BMC Plant Biologyogy, 6, 1. https://doi.org/10.1186/1471-2229-6-1

[101] Helliwell, C.A., et al. (2006) The Arabidopsis FLC Protein Interacts Directly in Vivo with SOC1 and FT Chromatin and Is Part of a High-Molecular-Weight Protein Complex. The Plant Journal, 46, 183-192. https://doi.org/10.1111/j.1365-313X.2006.02686.x

[102] Lee, J.H., et al. (2007) Role of SVP in the Control of Flowering Time by Ambient Temperature in Arabidopsis. Genes \& Development, 21, 397-402. https://doi.org/10.1101/gad.1518407

[103] Searle, I., et al. (2006) The Transcription Factor FLC Confers a Flowering Response to Vernalization by Repressing Meristem Competence and Systemic Signaling in Arabidopsis. Genes \& Development, 20, 898-912. https://doi.org/10.1101/gad.373506

[104] Ibáñez, C., et al. (2010) Circadian Clock Components Regulate Entry and Affect Exit of Seasonal Dormancy as Well as Winter Hardiness in Populus Trees. Plant Physiology, 153, 1823-1833. https://doi.org/10.1104/pp.110.158220

[105] McWatters, H.G., et al. (2000) The ELF3 Zeitnehmer Regulates Light Signalling to the Circadian Clock. Nature, 408, 716-720. https://doi.org/10.1038/35047079

[106] Harmer, S.L. (2009) The Circadian System in Higher Plants. Annual Review of Plant Biology, 60, 357-377. https://doi.org/10.1146/annurev.arplant.043008.092054

[107] McClung, C.R. (2006) Plant Circadian Rhythms. The Plant Cell, 18, 792-803. https://doi.org/10.1105/tpc.106.040980

[108] Bernard, R.L. (1972) Two Genes Affecting Stem Termination in Soybeans. Crop Science, 12, 235-239. https://doi.org/10.2135/cropsci1972.0011183X001200020028x

[109] Danilevskaya, O.N., Meng, X. and Ananiev, E.V. (2010) Concerted Modification of Flowering Time and Inflorescence Architecture by Ectopic Expression of TFL1-Like Genes in Maize. Plant Physiology, 153, 238-251. https://doi.org/10.1104/pp.110.154211

[110] Böhlenius, H., et al. (2006) CO/FT Regulatory Module Controls Timing of Flowering and Seasonal Growth Cessation in Trees. Science, 312, 1040-1043. https://doi.org/10.1126/science.1126038

[111] Eriksson, M.E. (2000) Role of Phytochrome A and Gibberellins in Growth under Long and Short Day Conditions. Swedish University of Agricultural Sciences.

[112] Ruonala, R., et al. (2008) CENL1 Expression in the Rib Meristem Affects Stem Elongation and the Transition to Dormancy in Populus. The Plant Cell, 20, 59-74. https://doi.org/10.1105/tpc.107.056721

[113] Pin, P. and Nilsson, O. (2012) The Multifaceted Roles of Flowering Locus T in Plant Development. Plant, Cell \& Environment, 35, 1742-1755. https://doi.org/10.1111/j.1365-3040.2012.02558.x

[114] Mohamed, R., et al. (2010) Populus CEN/TFL1 Regulates First Onset of Flowering, Axillary Meristem Identity and Dormancy Release in Populus. Plant Journal, 62, 674-688. https://doi.org/10.1111/j.1365-313X.2010.04185.x 
[115] Subburaj, S., et al. (2016) Phylogenetic Analysis, Lineage-Specific Expansion and Functional Divergence of Seed Dormancy 4-Like Genes in Plants. PLOS ONE, 11, e0153717. https://doi.org/10.1371/journal.pone.0153717

[116] Dennis, F.G.J. (1996) A Physiological Comparison of Seed and Bud Dormancy. In: Ga, L., Ed., Plant Dormancy, Physiology, Biochemistry and Molecular Biology, CAB International, Wallingford, 47-58.

[117] Okagami, N. (1986) Dormancy in Dioscorea-Different Temperature Adaptation of Seeds, Bulbils and Subterranean Organs in Relation to North-South Distribution. Botanical Magazine-Tokyo, 99, 15-27. https://doi.org/10.1007/BF02488619

[118] Baskin, J.M. and Baskin, C.C. (2004) A Classification System for Seed Dormancy. Seed Science Research, 14, 1-16. https://doi.org/10.1079/SSR2003150

[119] Duclos, D.V., et al. (2013) Investigating Seed Dormancy in Switchgrass (Panicum virgatum L.): Understanding the Physiology and Mechanisms of Coat-Imposed Seed Dormancy. Industrial Crops and Products, 45, 377-387.

[120] Finch-Savage, W.E. and Leubner-Metzger, G. (2006) Seed Dormancy and the Control of Germination. New Phytologist, 171, 501-523.

https://doi.org/10.1111/j.1469-8137.2006.01787.x

[121] Burson, B.L., Tischler, C.R. and Ocumpaugh, W.R. (2009) Breeding for Reduced Post-Harvest Seed Dormancy in Switchgrass: Registration of TEM-LoDorm Switchgrass Germplasm. Journal of Plant Registrations, 3, 99-103. https://doi.org/10.3198/jpr2008.07.0433crg

[122] Adkins, S.W., Bellairs, S.M. and Loch, D.S. (2002) Seed Dormancy Mechanisms in Warm Season Grass Species. Euphytica, 126, 13-20. https://doi.org/10.1023/A:1019623706427

[123] Costa, M.C.D., et al. (2016) Key Genes Involved in Desiccation Tolerance and Dormancy across Life Forms. Plant Science, 251, 162-168.

[124] Wan, J.M., et al. (2005) Quantitative Trait Loci Associated with Seed Dormancy in Rice. Crop Science, 45, 712-716. https://doi.org/10.2135/cropsci2005.0712

[125] Nakamura, S., et al. (2016) Mitogen-Activated Protein Kinase Kinase 3 Regulates Seed Dormancy in Barley. Current Biology, 26, 775-781.

[126] Lin, R., et al. (2009) QTL Mapping of Dormancy in Barley using the Harrington/Morex and Chevron/Stander Mapping Populations. Crop Science, 49, 841-849. https://doi.org/10.2135/cropsci2008.05.0269

[127] Willis, C.G., et al. (2014) The Evolution of Seed Dormancy: Environmental Cues, Evolutionary Hubs, and Diversification of the Seed Plants. New Phytologist, 203, 300-309. https://doi.org/10.1111/nph.12782

[128] Okamoto, M., et al. (2006) CYP707A1 and CYP707A2, Which Encode Abscisic Acid 8'-Hydroxylases, Are Indispensable for Proper Control of Seed Dormancy and Germination in Arabidopsis. Plant Physiology, 141, 97-107. https://doi.org/10.1104/pp.106.079475

[129] Okamoto, M., et al. (2010) Genome-Wide Analysis of Endogenous Abscisic Acid-Mediated Transcription in Dry and Imbibed Seeds of Arabidopsis using Tiling Arrays. The Plant Journal, 62, 39-51. https://doi.org/10.1111/j.1365-313X.2010.04135.x

[130] Qin, X. and Zeevaart, J.A. (2002) Overexpression of a 9-cis-Epoxycarotenoid Dioxygenase Gene in Nicotiana plumbaginifolia Increases Abscisic Acid and Phaseic Acid Levels and Enhances Drought Tolerance. Plant Physiology, 128, 544-551. https://doi.org/10.1104/pp.010663 
[131] Thompson, A.J., et al. (2000) Ectopic Expression of a Tomato 9-cis-Epoxycarotenoid Dioxygenase Gene Causes Over-Production of Abscisic Acid. The Plant Journal, 23, 363-374. https://doi.org/10.1046/j.1365-313x.2000.00789.x

[132] Hilhorst, H.W.M. and Karssen, C.M. (1992) Seed Dormancy and Germination: The Role of Abscisic Acid and Gibberellins and the Importance of Hormone Mutants. Plant Growth Regulation, 11, 225-238. https://doi.org/10.1007/BF00024561

[133] Kermode, A.R. (2005) Role of Abscisic Acid in Seed Dormancy. Journal of Plant Growth Regulation, 24, 319-344. https://doi.org/10.1007/s00344-005-0110-2

[134] Ofir, M. and Kigel, J. (1998) Abscisic Acid Involvement in the Induction of Summer-Dormancy in Poa bulbosa, a Grass Geophyte. Physiologia Plantarum, 102, 163-170. https://doi.org/10.1034/j.1399-3054.1998.1020202.x

[135] Urano, K., et al. (2016) Analysis of Plant Hormone Profiles in Response to Moderate Dehydration Stress. The Plant Journal.

[136] Zheng, C., et al. (2015) Abscisic Acid (ABA) Regulates Grape Bud Dormancy, and Dormancy Release Stimuli May Act through Modification of ABA Metabolism. Journal of Experimental Botany, 66, 1527-1542. https://doi.org/10.1093/jxb/eru519

[137] Cline, M.G. and Oh, C. (2006) A Reappraisal of the Role of Abscisic Acid and Its Interaction with Auxin in Apical Dominance. Annals of Botany, 98, 891-897. https://doi.org/10.1093/aob/mcl173

[138] Avendaño López, A.N., et al. (2011) Seed Dormancy in Mexican Teosinte. Crop Science, 51, 2056-2066. https://doi.org/10.2135/cropsci2010.09.0538

[139] Powell, L.E. (1987) Hormonal Aspects of Bud and Seed Dormancy in Temperate-Zone Woody-Plants. Hortscience, 22, 845-850.

[140] Mohapatra, S.S., Poole, R.J. and Dhindsa, R.S. (1988) Abscisic Acid-Regulated Gene Expression in Relation to Freezing Tolerance in Alfalfa. Plant Physiology, 87, 468-473. https://doi.org/10.1104/pp.87.2.468

[141] Koornneef, M., Bentsink, L. and Hilhorst, H. (2002) Seed Dormancy and Germination. Current Opinion in Plant Biology, 5, 33-36.

[142] Kucera, B., Cohn, M.A. and Leubner-Metzger, G. (2005) Plant Hormone Interactions during Seed Dormancy Release and Germination. Seed Science Research, 15, 281-307. https://doi.org/10.1079/SSR2005218

[143] Toh, S., et al. (2008) High Temperature-Induced Abscisic Acid Biosynthesis and Its Role in the Inhibition of Gibberellin Action in Arabidopsis Seeds. Plant Physiology, 146, 1368-1385. https://doi.org/10.1104/pp.107.113738

[144] Grappin, P., et al. (2000) Control of Seed Dormancy in Nicotiana plumbaginifolia: Post-Imbibition Abscisic Acid Synthesis Imposes Dormancy Maintenance. Planta, 210, 279-285. https://doi.org/10.1007/PL00008135

[145] Finkelstein, R. (2010) The Role of Hormones during Seed Development and Germination. In: Davies, P., Eds., Plant Hormones, Springer, 549-573.

https://doi.org/10.1007/978-1-4020-2686-7_24

[146] Corbineau, F., et al. (2002) Breakage of Pseudotsuga menziesii Seed Dormancy by Cold Treatment as Related to Changes in Seed ABA Sensitivity and ABA Levels. Physiologia Plantarum, 114, 313-319. https://doi.org/10.1034/j.1399-3054.2002.1140218.x

[147] Argyris, J., et al. (2008) Genetic Variation for Lettuce Seed Thermoinhibition Is Associated with Temperature-Sensitive Expression of Abscisic Acid, Gibberellin, and Ethylene Biosynthesis, Metabolism, and Response Genes. Plant Physiology, 148, 926-947. https://doi.org/10.1104/pp.108.125807 
[148] Mauriat, M., Sandberg, L.G. and Moritz, T. (2011) Proper Gibberellin Localization in Vascular Tissue Is Required to Control Auxin-Dependent Leaf Development and Bud Outgrowth in Hybrid Aspen. The Plant Journal, 67, 805-816. https://doi.org/10.1111/j.1365-313X.2011.04635.x

[149] Mornya, P.M.P. and Cheng, F. (2013) Seasonal Changes in Endogenous Hormone and Sugar Contents during Bud Dormancy in Tree Peony. Journal of Applied Hor ticulture (Lucknow), 15, 159-165.

[150] Henschke, M., Pers, K. and Opalińska, S. (2016) Post-Harvest Longevity of Ornamental Grasses Conditioned in Gibberellic Acid and 8-Hydroxyquinoline Sulphate. Folia Horticulturae, 28, 51-56. https://doi.org/10.1515/fhort-2016-0007

[151] Han, Q.-F., et al. (2011) Characteristics of Endogenous Hormone Variations in the Roots of Alfalfa (Medicago sativa L.) Cultivars of Different Fall Dormancies during Spring Regrowth Stage. Agricultural Sciences in China, 10, 1032-1040.

[152] Zhuang, W., et al. (2015) Metabolic Changes upon Flower Bud Break in Japanese Apricot Are Enhanced by Exogenous GA4. Horticulture Research, 2, 15046. https://doi.org/10.1038/hortres.2015.46

[153] Hartmann, A., et al. (2011) Reactivation of Meristem Activity and Sprout Growth in Potato Tubers Require Both Cytokinin and Gibberellin. Plant Physiology, 155, 776-796. https://doi.org/10.1104/pp.110.168252

[154] Leyser, O. (2003) Regulation of Shoot Branching by Auxin. Trends in Plant Science, 8, 541-545.

[155] Shim, D., et al. (2014) A Molecular Framework for Seasonal Growth-Dormancy Regulation in Perennial Plants. Horticulture Research, 1, 14059. https://doi.org/10.1038/hortres.2014.59

[156] Paul, S., et al. (2016) Tissue- and Cell-Specific Cytokinin Activity in Populus $\times$ Canescens Monitored by ARR5: GUS Reporter Lines in Summer and Winter. Frontiers in Plant Science, 7, 652-652. https://doi.org/10.3389/fpls.2016.00652

[157] Cunningham, S., et al. (2003) Raffinose and Stachyose Accumulation, Galactinol Synthase Expression, and Winter Injury of Contrasting Alfalfa Germplasms. Crop Science, 43, 562-570. https://doi.org/10.2135/cropsci2003.0562

[158] Castonguay, Y., et al. (2009) An Indoor Screening Method for Improvement of Freezing Tolerance in Alfalfa. Crop Science, 49, 809-818. https://doi.org/10.2135/cropsci2008.09.0539

[159] Castonguay, Y., et al. (2013) Molecular Physiology and Breeding at the Crossroads of Cold Hardiness Improvement. Physiologia Plantarum, 147, 64-74. https://doi.org/10.1111/j.1399-3054.2012.01624.x

[160] Adhikari, L., et al. (2015) Testing the Efficacy of a Polyester Bagging Method for Selfing Switchgrass. BioEnergy Research, 8, 380-387. https://doi.org/10.1007/s12155-014-9528-3

[161] https://phytozome.jgi.doe.gov/pz/portal.html\#!gene?search=1\&detail=1\&method=5 010\&searchText=transcriptid:32804221

[162] Liu, X. and Chu, Z. (2015) Genome-Wide Evolutionary Characterization and Analysis of bZIP Transcription Factors and Their Expression Profiles in Response to Multiple Abiotic Stresses in Brachypodium distachyon. BMC Genomics, 16, 227. https://doi.org/10.1186/s12864-015-1457-9

[163] Conesa, A., et al. (2005) Blast2GO: A Universal Tool for Annotation, Visualization and Analysis in Functional Genomics Research. Bioinformatics, 21, 3674-3676. https://doi.org/10.1093/bioinformatics/bti610 
[164] Goff, S.A., et al. (2011) The iPlant Collaborative: Cyberinfrastructure for Plant Biology. Frontiers in Plant Science, 2, 34. https://doi.org/10.3389/fpls.2011.00034

[165] Lyons, E., et al. (2014) Comparative Genomics of Grass Genomes using CoGe. In: Handbook of Plant and Crop Physiology, 3rd Edition, CRC Press, 797-816. https://doi.org/10.1201/b16675-44

[166] Kebrom, T.H., Brutnell, T.P. and Finlayson, S.A. (2010) Suppression of Sorghum Axillary Bud Outgrowth by Shade, phyB and Defoliation Signalling Pathways. Plant, Cell \& Environment, 33, 48-58.

[167] Sun, M.-Y., et al. (2016) Analysis of Basic Leucine Zipper Genes and Their Expression during Bud Dormancy in Peach (Prunus persica). Plant Physiologyogy and Biochemistry, 104, 54-70.

[168] Ubi, B.E., et al. (2010) Molecular Cloning of Dormancy-Associated MADS-Box Gene Homologs and Their Characterization during Seasonal Endodormancy Transitional Phases of Japanese Pear. Journal of the American Society for Horticultural Science, 135, 174-182.

[169] Yamane, H., et al. (2011) Expressional Regulation of PpDAM5 and PpDAM6, Peach (Prunus persica) Dormancy-Associated MADS-Box Genes, by Low Temperature and Dormancy-Breaking Reagent Treatment. Journal of Experimental Botany, 62, 3481-3488. https://doi.org/10.1093/jxb/err028

[170] Ito, Y. and Nakano, T. (2015) Development and Regulation of Pedicel Abscission in Tomato. Frontiers in Plant Science, 6, 442. https://doi.org/10.3389/fpls.2015.00442

[171] Zhao, Q., et al. (2011) MADS-Box Genes of Maize: Frequent Targets of Selection during Domestication. Genetics Research, 93, 65-75.

https://doi.org/10.1017/S0016672310000509

[172] Voogd, C., Wang, T. and Varkonyi-Gasic, E. (2015) Functional and Expression Analyses of Kiwifruit SOC1-Like Genes Suggest That They May Not Have a Role in the Transition to Flowering But May Affect the Duration of Dormancy. Journal of Experimental Botany, 66, 4699-4710. https://doi.org/10.1093/jxb/erv234

[173] Kebrom, T.H., et al. (2010) Vegetative Axillary Bud Dormancy Induced by Shade and Defoliation Signals in the Grasses. Plant Signaling \& Behavior, 5, 317-319. https://doi.org/10.4161/psb.5.3.11186

[174] Stafstrom, J.P., et al. (1998) Dormancy-Associated Gene Expression in Pea Axillary Buds. Planta, 205, 547-552. https://doi.org/10.1007/s004250050354

[175] Goldmark, P.J., Dykes, J. and Walker-Simmons, M.K. (1993) Expression of a Bromus secalinus Transcript Associated with Seed Dormancy in Avena fatua and Other Grass Weeds, in Pre-Harvest Sprouting in Cereals 1992. American Association of Cereal Chemists, St Paul, 312-316.

[176] Barrero, J.M., et al. (2012) Grain Dormancy and Light Quality Effects on Germination in the Model Grass Brachypodium distachyon. New Phytologist, 193, 376-386. https://doi.org/10.1111/j.1469-8137.2011.03938.x

[177] Li, C., et al. (2004) Genes Controlling Seed Dormancy and Pre-Harvest Sprouting in a Rice-Wheat-Barley Comparison. Functional \& Integrative Genomics, 4, 84-93. https://doi.org/10.1007/s10142-004-0104-3

[178] Ye, H., Foley, M.E. and Gu, X.-Y. (2010) New Seed Dormancy Loci Detected from Weedy Rice-Derived Advanced Populations with Major QTL Alleles Removed from the Background. Plant Science, 179, 612-619.

[179] Gu, X.-Y., et al. (2010) The qSD12 Underlying Gene Promotes Abscisic Acid Accumulation in Early Developing Seeds to Induce Primary Dormancy in Rice. Plant Molecular Biology, 73, 97-104. https://doi.org/10.1007/s11103-009-9555-1 
[180] Larson, S.R. and Kellogg, E.A. (2009) Genetic Dissection of Seed Production Traits and Identification of a Major-Effect Seed Retention qtl in Hybrid Leymus (Triticeae) Wildryes. Crop Science, 49, 29-40.

https://doi.org/10.2135/cropsci2008.05.0277

[181] Bentsink, L., et al. (2006) Cloning of DOG1, a Quantitative Trait Locus Controlling Seed Dormancy in Arabidopsis. Proceedings of the National Academy of Sciences of the United States of America, 103, 17042-17047.

https://doi.org/10.1073/pnas.0607877103

[182] Graeber, K., et al. (2012) Molecular Mechanisms of Seed Dormancy. Plant, Cell \& Environment, 35, 1769-1786. https://doi.org/10.1111/j.1365-3040.2012.02542.x

[183] Nakamura, S., et al. (2011) A Wheat Homolog of Mother of Ft and TFL1 Acts in the Regulation of Germination. Plant Cell, 23, 3215-3229.

https://doi.org/10.1105/tpc.111.088492

[184] Penfield, S. and Hall, A. (2009) A Role for Multiple Circadian Clock Genes in the Response to Signals That Break Seed Dormancy in Arabidopsis. The Plant Cell, 21, 1722-1732. https://doi.org/10.1105/tpc.108.064022

[185] Shu, K., et al. (2016) Two Faces of One Seed: Hormonal Regulation of Dormancy and Germination. Molecular Plant, 9, 34-45.

[186] Liu, Q., et al. (2015) Does Gibberellin Biosynthesis Play a Critical Role in the Growth of Lolium Perenne? Evidence from a Transcriptional Analysis of Gibberellin and Carbohydrate Metabolic Genes after Defoliation. Frontiers in Plant Science, 6, 944. https://doi.org/10.3389/fpls.2015.00944

\section{Abbreviations}

ABA: Abscisic Acid

ABI: Aba-Insensitive

ARF: Auxin Response Factors

ATE: Arginyl-Trna: Protein Arginyltransferase

AUX: Auxin

BZIP: Leucine Zipper

CAS: Cold Acclimation Specific Genes

CBF: C Repeat Binding Factor

CCA: Circadian Clock Associated

CENL 1: Centroradialis-Like 1

CHO1: Chotto1

CO: Constans

COR: Cold-Regulate Gene

DAG1: Dof Affecting Germination 1

DAM: Dormancy-Associated Mads-Box

DDF : Dwarf And Delayed Flowering 1

DOG: Delay Of Germination

DRM: Dormancy-Associated Protein Gene

ELF: Early Flowering 
ET: Ethylene

FLC: Flowering Locus C

FT: Flowering Locus T

FUS: Fusca

GA: Gibberellic Acid

GA2OXS: Gibberellin 2- Oxidases

GI: Gigantia

GID1: Ga-Insensitive Dwarf1

HAB: Hypersensitive To Aba

HSP: Heat Shock Proteins

HUB1: Histone Monoubiquitination 1

IAA: Indole-3-Acetic Acid

KYP: Kryptonite

LEC: Leafy Cotyledons

LHY: Late Elongated Hypocotyl

LUX: Lux Arrhythmo

MAX2: More Axillary Growth

NCED: 9-Cis-Epoxycarotenoid Dioxygenase

PHY: Phytochrome

PIF3: Phtochrome-Interacting Factor3

RDO: Reduced Dormancy

RGA: Repressor Of Ga1-3

RGL: Rga-Like

SCF: Skp1-Cullin-F-Box

SDR4: Seed Dormancy Gene 4

SLY: Sleepy

SOC1: Suppressor Of Overexpression Of Constans 1

SOM: Somnus

SPT: Spatula

SPY: Spindly

SVP: Short Vegetative Phase

TB: Teosinte Branched

TFL: Terminal Flower

TOC 1: Timing Of Cab 1

VP 1: Viviparous 1

ZCN1: Zea Centroradialis

ZTL: Zeitlupe 